\title{
PRELIMINARY PROGRAM
}

I INTERAMERICAN METEOROLOGICAL CONGRESS - IV BRAZILIAN METEOROLOGICAL CONGRESS October 20-24, 1986, Brasilia, Brazil

\section{GENERAL INFORMATION}

INSTRUMENTAL EXHIBITS

PAPERS PRESENTATION

\section{ACCOMMODATIONS}

\section{REGISTRATION}

TRANSPORTATION
The I Interamerican Meteorological Congress and the IV Brazilian Meteorological Congress will be held 20-24 October 1986 in Brasilia, Brazil. The Congress is being cosponsored by Brazilian Meteorological Society (SBMET), Argentinean Center of Meteorologists (CAM) and the American Meteorological Society (AMS). The purpose of the Congress is to bring together an International group for an interchange of ideas on current research in weather forecasting and to outline present and future needs of this technology in the South American countries. All sessions will be held at FUNCEP (Training Center for Civil Service) SAIS, area \#1, Brasilia, Brazil.

Commercial exhibits of meteorological instruments will be on display during the Congress. Those interested in displaying equipment should contact the Organizing Committee in Brasilia, Brazil.

In addition to papers relating to the general theme, sessions will be held on other aspects of meteorology depending on contributions. The deadline for abstracts has passed. Authors of accepted abstracts will receive instructions concerning data and time of presentation. The deadline for papers is 31 August 1986. The full papers are limited to a maximum of six pages in order to be included in the Congress Proceedings. Extended papers can be submitted to Brazilian Meteorological Journal. The official languages of the Congress are Portuguese, Spanish and English. Fifteen minutes will be assigned for a paper presentation.

Accommodations are available at the following hotels (all rates quoted in US dollars): Garvey (four star hotel) $\$ 60$ single; $\$ 69$ double: Aracoara (four star hotel) $\$ 61$ single; $\$ 75$ double: Byblos (three star hotel) $\$ 29$ single; $\$ 33$ double: Diplomat (three star hotel) $\$ 34$ single; $\$ 39$ double: Aristus (two star hotel) $\$ 18$ single; $\$ 27$ double. Prices include breakfast. Checkout time is noon. To make a reservation send your name, affiliation, address, arrival and departure dates, and your first and second choices of hotel (specify single or double room) to Comite Organizador, I Congresso Interamericano de Meteorologia, Instituto Nacional de Meteorologia, Eixo Monumental, Via SI Cruzeiro, 70650 - Brasilia, DF, Brasil.

To pre-register, send name, affiliation, address and appropriate fee to Comite Organizador I Congresso Interamericano de Meteorologia, Instituto Nacional de Meteorologia, Eixo Monumental, Via SI Cruzeiro, 70650 - Brasilia, DF, Brasil. The registration fee (rates quoted in US dollars) before 24 October 1986 is $\$ 11$ for SBMET/CAM/AMS members; $\$ 15$ for nonmembers; and $\$ 26$ for institutions (three participants). Registration fee includes the Congress proceedings.

Brasilia is served by an International Airport ( 15 minutes from downtown area). VARIG Brazilian Airline is the official transportation airline of the Congress. $\begin{array}{cllll}\text { Telephone: } & \text { New York } & (212) 340-0200 & \text { Los Angeles } & \text { (213) 683-1870 } \\ \text { Miami } & \text { (305) } 592-1188 & \text { New Orleans } & \text { (504) 895-7031 }\end{array}$

Organizing Committee:

INSTITUTO NACIONAL DE METEOROLOGIA (INMET)

Eixo Monumental, Via Sl Cruzeiro

70650-Brasilia, DF, Brasil

Tel.: (061) 224-7944 or 225-0830; Telex: (061) 1364

A/C: Francisco de Assis Diniz 
SOCIEDADE BRASILEIRA DE METEOROLOGIA (SBMET)

Av. Jose Candido da Silveira, 2000 - Horto

31170-Belo Horizonte-MG

Tel.: (031) 461-7933 - ramal 205 or 303; Telex: (031) 1031

A/C: Heloisa Moreira Torres Nunes, Julio Cesar Santos Chagas, or Maria Luiza Pimentel de Sousa

CENTRO ARGENTINO DE METEOROLOGOS (CAM)

Departmento de Meteorologia

Faculdad de Ciencias Exactas Y Naturales

Pabellon n0 2, Ciudad Universitaria

CEP: 1428-Buenos Aires-Argentina

Tel.: (541) 782-6528 or 312-4991

A/C: Mario Nunez, or Victor J. Leis

\author{
AMERICAN METEOROLOGICAL SOCIETY (AMS) \\ 45 Beacon Street \\ Boston, Massachusetts, 02108 USA \\ Tel.: (617) 227-2425 \\ A/C: Dr. Kenneth C. Spengler
}

\begin{tabular}{|c|c|}
\hline October 20 & $\begin{array}{l}\text { - Registration } \\
\text { - Opening session } \\
\text { - Opening of Technical Exhibition } \\
\text { - Conference - Climatic Analysis: Present status, } \\
\text { Agriculture, Hydrology and Civil Defense Applications } \\
\text { - Session 1 - papers presentation }\end{array}$ \\
\hline October 21 & $\begin{array}{l}\text { - Workshop - Agrometeorological and Hydrometeorological } \\
\quad \text { Alert Systems } \\
\text { - Session II - papers presentation } \\
\text { - Session III - papers presentation } \\
\text { - Session IV - papers presentation }\end{array}$ \\
\hline October 22 & $\begin{array}{l}\text { - Workshop - International Cooperation in Meteorology - } \\
\text { Brazil-Argentina-United States } \\
\text { - Conference - The Use of Radar Satellites Data } \\
\text { for Analysis and Weather Forecast } \\
\text { - General Ordinary SBMET Assembly } \\
\text { - General Extraordinary SBMET Assembly-Election of SBMET } \\
\text { Officers } \\
\text { Panel - The Meteorological Aspects in the New Brazilian } \\
\text { Constitution Project }\end{array}$ \\
\hline October 23 & $\begin{array}{l}\text { - Workshop - Atmospheric Pollution Forecasting and Control } \\
\text { - Session V - papers presentation } \\
\text { - Session VI - papers presentation } \\
\text { - Session VII - papers presentation }\end{array}$ \\
\hline October 24 & $\begin{array}{l}\text { - Conclusions and recommendations reports of Workshops, } \\
\text { Conferences and Meetings } \\
\text { - Foundation of the Latin-American Meteorological } \\
\text { Societies Confederation } \\
\text { - Closing session }\end{array}$ \\
\hline
\end{tabular}

Two workshops are planned for October 17 and 18, preceding the main events:

Workshop: Meteorological Instrumentation - Present status of surface and upper air networks. Nonconventional instruments. The aspects of importing versus national manufacturing.

Workshop: Cloud Seeding - Present status of theoretical and experimental knowledge. The aspects of hail suppression - the application in Santa Catarina State in the apple cultures region. The cloud seeding experiments in Brazil and its controversial use. Two hours have been designated for the workshops, conferences and sessions, one hour for presentation and one for debate. 


\section{Introducing the LI-1000 DataLogger... Now you can buy both a light meter and a datalogger for one, very affordable price: $\$ 790 . *$}

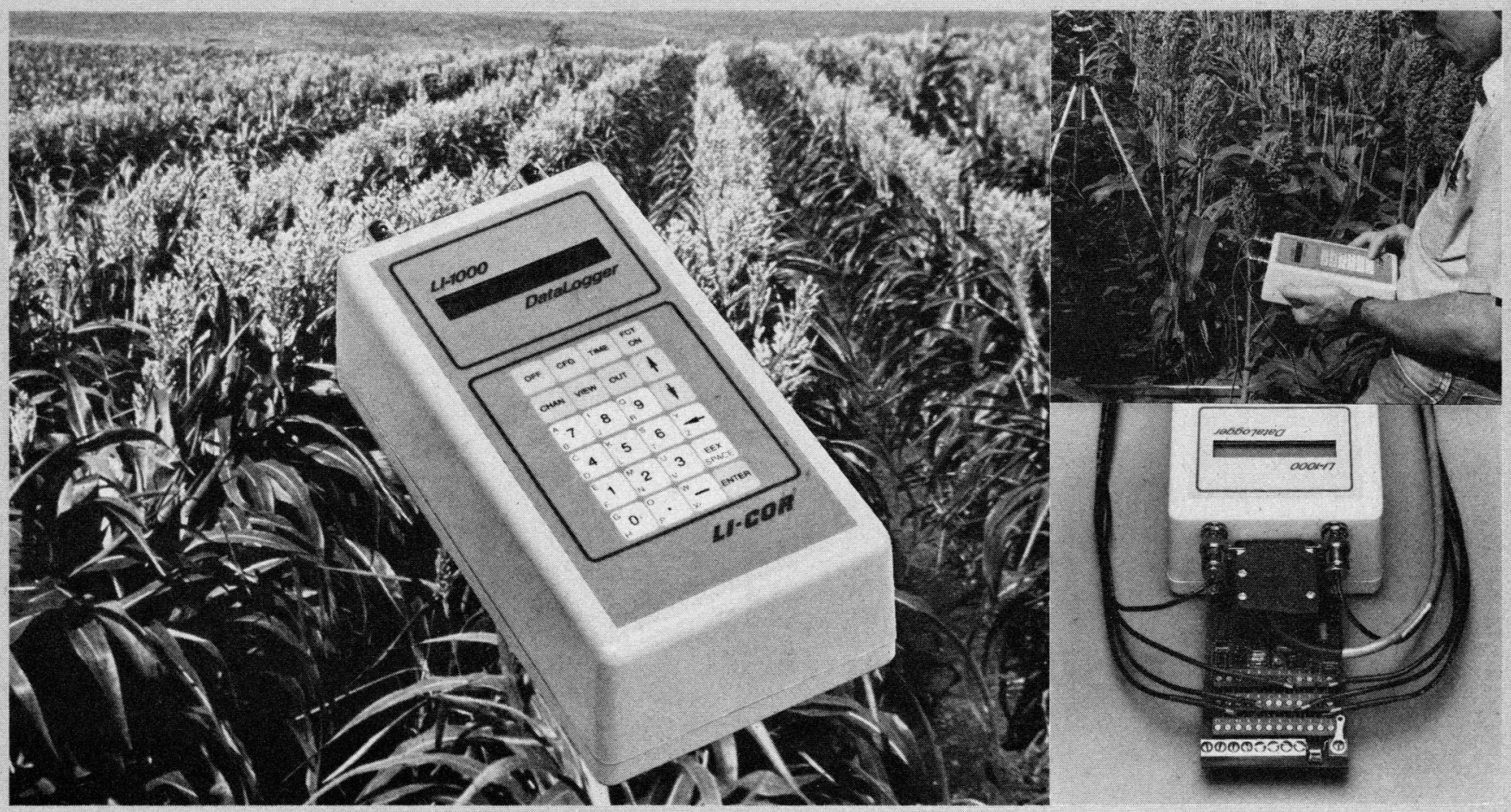

Whether your application requires a simple meter or a more sophisticated datalogger, the new LI-COR LI-1000 DataLogger has the capability to meet your needs. The LI-1000 combines simple operation, compact size, and 10 channel logging capability to produce a system that is both powerful and easy to use. The LI-1000's features include:

\section{CHANNELS}

- 6 current or voltage

- 2 current only

- 2 digital pulse counting

- Resolution: 25 picoamps/2.5 uV typical.

\section{EASY TO USE SOFTWARE}

Menu driven software allows the LI-1000 to be quickly configured to meet your application. Commonly used routines are assigned to function keys so that only one keystroke initiates the routine. Each routine guides you by prompting for data and providing default values where data need not always be entered.

\section{LIGHT METER OPERATION}

In Instantaneous Mode the LI-1000 acts as a simple meter providing direct readout for up to $8 \mathrm{LI}$-COR sensors or other types of sensors. The LI-1000's autoranging capability allows measurement over a wide dynamic range without having to use a range selection switch. Instantaneous values from all sensors can be stored in memory with a single keystroke.

\section{DATALOGGING OPERATION}

In Datalogging Mode each channel can be separately configured to collect data over periods of 10 minutes, $1,3,6,12$, or 24 hours (user selectable). Data can be collected as an integrated, averaged or point value. Each data point is stored with a time stamp from the LI-1000's real time clock. Other features allow storage of max/min values, ratio's of channels and more.

\section{DATA STORAGE}

The LI-1000 is available with $8 \mathrm{~K}$ RAM, or with 32K RAM for long term data logging applications. With $32 \mathrm{~K}$ RAM you can store over 6000 data points.

\section{DATA OUTPUT}

Data can easily be read back and transcribed from the LI-1000's LCD display, or an RS-232C output port provides rapid data transfer to a computer, printer, or terminal.

\section{ENVIRONMENTALLY SEALED}

The LI-1000's O-ring sealed, weatherproof case protects it from harsh environmental conditions. Its six D cell batteries provide $6-10$ months of operation for long term logging.

\section{APPLICATIONS}

- Solar radiation monitoring

- Underwater light profiling

- Illumination and daylighting studies

- Plant canopy profiling

- Meteorological measurements

- Temperature measurement ....and many more.

For more information call us at (402) 467-3576. Or, write: LI-COR, Box 4425, Lincoln, NE 68504. USA. TWX: 910-6218116

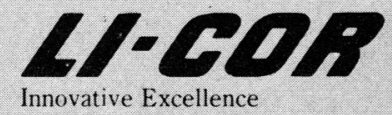


The first issue of Weather and Forecasting, a new AMS periodical, was published in June of 1986. This quarterly journal is intended to serve those who are engaged primarily in operational forecasting or who are involved in research that is directed toward better understanding of weather events that present significant operational forecast problems.

The emphasis of most contributions to Weather and Forecasting will be nowcasting or short-range and medium-range forecasting. Examples of topics the journal will address are: operational forecasting techniques; applications of new analysis methods; forecasting verification studies; and mesoscale and synoptic-scale case studies that have direct applicability to forecasting. Special sections of Weather and Forecasting will include:

1. Articles

2. Notes and Correspondence

3. Forecasting Techniques
4. Computer Techniques

5. Forecaster's Forum

6. Forecaster's Biography

\section{Weather}

and

Forecasting

American Meteorological Society

7. Photo of the Quarter

TO SUBSCRIBE

Members

Nonmembers
$\$ 20.00$

$\$ 80.00$
Please send order and remittance in U.S. dollars (foreign subscribers add $\$ 15.00$ for surface postage and handling) to:
June

1986

Volume 1 Numbers 1 and 2

\section{Weather and Forecasting American Meteorological Society 45 Beacon St. Boston, MA 02108}




\section{PROGRAM}

FIFTH JOINT CONFERENCE ON APPLICATIONS OF AIR POLLUTION METEOROLOGY WITH APCA OF THE AMERICAN METEOROLOGICAL SOCIETY, NOVEMBER 18-21, 1986, CHAPEL HILL, NC.

AMS NATIONAL OFFICERS

1986 AMS COMMITTEE ON METEOROLOGICAL ASPECTS OF AIR POLLUTION

PROGRAM COMMITTEE

LOCAL ARRANGEMENTS COMMITTEE

SYNOPSIS OF SESSIONS
President: Joseph Smagorinsky President Elect: Albert J. Kaehn, Jr. Executive Director: Kenneth C. Spengler
William Porch, Chmn.

Sumner Barr

Gary A. Briggs

John F. Clarke, Co-Chmn.

Paul Arya

Sumner Barr

Francis S. Binkowski

Jason K. S. Ching

Terry L. Clark

Brian K. Eder

Nov 17 Mon

Nov 18 Tue

Nov 19 Wed

Nov 20 Thurs $8: 1$

\begin{tabular}{|c|c|c|}
\hline \multirow[b]{4}{*}{ Nov 20} & & $\begin{array}{r}9: 35 \\
10: 05 \\
10: 30\end{array}$ \\
\hline & & $\begin{array}{r}12: 05 \\
1: 30\end{array}$ \\
\hline & & $\begin{array}{l}3: 05 \\
3: 30\end{array}$ \\
\hline & Fri & $\begin{array}{r}6: 00 \\
8: 15 \\
9: 45 \\
10: 10 \\
11: 35\end{array}$ \\
\hline
\end{tabular}

$7: 30$ am

8:00 am

$8: 10$ am

$8: 15$ am

9:35 am

10:05 am

$10: 30$ am

12:05 pm

$1: 30 \mathrm{pm}$

3:05 pm

3:30 pm

$5: 30 \mathrm{pm}$

9:35 am

10:05 am

10:30 am

12:05 pm

$1: 30 \mathrm{pm}$

3:05 pm

$3: 30 \mathrm{pm}$

$6: 30 \mathrm{pm}$
Jason K. S. Ching

Raymond J. Deland

Ramesh Godbole

John W. Wilson, Co-Chmn. James L. Dicke George Greenly Mark L. Kramer K. Misra
Mark L. Kramer P. K. Misra F. Schier meier David B. Smith Joseph A. Tikvart
Robert E. Eskridge

D. Bruce Turner

Registration

Registration (continued)

eming Remarks

Session 1: Air Pollution Modeling on the

Regional Scale

Session Pl: Summary of First Poster Session

Coffee Break

Session 2: Evaluation of Regional-Scale Models

Lunch Break

Session 3: Evaluation of Regional-Scale

Coffee Break

Trajectory Techniques

Session 4: Analysis of Regional-Scale Pollution Icebreaker (cash bar)

Session 5: Physical and Chemical Processes for Regional Models I

Session P2: Summary of Second Poster Session Coffee Break

Session 6: Physical and Chemical Processes for Lunch Break Regional Models II

Session 7: Mesoscale Models and Processes

Coffee Break

Session 8: Regulatory Applications

Cocktail Hour

Banquet

Session 9: Complex Terrain Models/Field Studies I

Session P3: Summary of Third Poster Session

Coffee Break

Session 10: Complex Terrain Models/Field Studies II

Lunch Break

Coffee Break Assessment I

Session 12: Toxic Chemical Releases and Risk Assessment II

"Down Home" Pig Pickin'

Session 13: Advances in Dispersion Techniques I Coffee Break

Session 14: Advances in Dispersion Techniques II

Poster Awards and Closing Remarks 
GENERAL INFORMATION

\section{ACCOMMODATIONS}

\section{REGISTRATION}

TRANSPORTATION

SPOUSES' COFFEE

ICEBREAKER

COCKTAIL HOUR AND BANQUET

NORTH CAROLINA PIG PICKIN'

TENNIS
The Fifth Joint Conference on Applications of Air Pollution Meteorology, sponsored by the American Meteorological Society and the Air Pollution Control Association, will be held November 18-21, 1986 at the Hotel Europa in Chapel Hill, N.C. The focus of the meeting will be regional-scale modeling, evaluation and processes.

All sessions will be held at the Hotel Europa, Chapel Hill, N.C. A block of rooms has been set aside for the meeting at the following special rates: $\$ 53$ single; $\$ 66$ double (plus tax). Reservations must be received prior to October 27, 1986. A one night deposit is required when making reservations. Check-in time is 3:00pm; check-out time is 12 noon. The hotel provides complimentary transportation to and from Raleigh-Durham Airport for all hotel guests. These arrangements can be made directly with the hotel when making reservations. Contact: Hotel Europa, Europa Drive, Chapel Hill, NC 27514 (tel.: 919-968-4900). For special rates, be sure to mention the American Meteorological Society's name when making reservations.

The conference registration desk will be open Monday, November 17 from 7:30 pm and on Tuesday through Friday from 7:30 am. Pre-registration fees are: $\$ 105$, AMS/APCA members, speakers and session chairmen; $\$ 125$, nonmembers; $\$ 65$, Central Nor th Carolina Chapter members, undergraduate and graduate students. In order to receive pre-registration rates, payment must be received by Nov. 7, 1986. Registration fees at the meeting are: $\$ 120$, AMS/APCA members, speakers and session chairmen; $\$ 140$, nonmembers; $\$ 75$ Central North Carolina Chapter members; undergraduate and graduate students, AMS members 65 or older, not regularly employed. The registration fee includes a preprint volume and a banquet ticket. Preprint volumes will be available and distributed at the time of the conference. We urge you to preregister by sending the appropriate remittance together with your name, affiliation and complete mailing address to: American Meteorological Society, 45 Beacon St., Boston, MA 02108, Attn: Fifth Joint Conference on Air Pollution.

Raleigh-Durham airport is located 25 miles southeast of Chapel Hill and is serviced by limousine and rental cars. The Hotel Europa provides complimentary transportation for hotel guests (reservation required).

A coffee get-together for spouses, families and guests of conference registrants will be held on Tuesday, November 19, at 10:00 am. Room information will be available at the AMS registration desk. There is no formal social program planned. The coffee get-together will enable guests to become acquainted and to plan activities, should they wish. Information on activities in the area will be available at that time.

An Icebreaker (cash bar) will be held Tuesday, November 18, at 5:30 pm.

There will be a Banquet on Wednesday, November 19 at 7:30 pm, preceded by a Cocktail Hour (cash bar) at 6:30 pm. Additional banquet tickets will be available for purchase at the AMS registration desk for $\$ 20$ before 12 noon, Tuesday, Nov. 18 .

A "down home" Nor th Carolina "Pig Pickin'" will be held Thursday at 6:00 pm. The cost of this function will be $\$ 17$ and will include North Carolina barbeque and barbequed chicken. Preregistrants should indicate their desire to attend this function. Additional tickets will be available for purchase at the AMS registration desk before 12 noon, Tuesday, Nov. 18.

Three lighted tennis courts are available at the hotel for the use of the conference participants. We plan an AMS/APCA doubles tennis tournament. This is designed to be a major social event and will be open to all conference participants and their guests. Please contact Jason Ching (tel.: 919-541-4801) or Robert Eskridge (tel.: 919-541-4551) MD-80, Meteorology and Assessment Divison, Environmental Protection Agency, Research Triangle Park, NC 27711 (tel.:919-541-4801 or 919-541-4551). Please indicate your interest and specify your skill level on a scale of 1 (beginner) to 5 (John McEnroe) to assist us in planning this event. Matches will begin Tuesday evening (after the Icebreaker). The criteria for participation are a desire for fun, for meeting people and a tennis racket. A nominal fee of $\$ 3.00$ will be assessed for tennis balls and awards.

The weather in Chapel Hill, N.C. during the end of November is generally cool and dry. Daily temperatures range from the upper $50^{\prime} \mathrm{s}\left({ }^{\circ} \mathrm{F}\right)$ during the afternoon to the low 30's at night. November tends to be one of the driest months in the year with measurable precipitation falling only once every four days. Prevailing winds are southwesterly at speeds less than $10 \mathrm{mph}$. 


\section{PROGRAM}

TUES NOV 18 8:10 AM

8:15 AM

\section{WELCOMING REMARKS}

\section{SESSION 1: AIR POLLUTION MODELING ON THE REGIONAL SCALE}

Chairpersons: Kenneth L. Demerjian, State Univ. of New York (SUNY) at Albany, Albany, N.Y.; and Ronald R. Stoner, NUS Corp., Gaithersburg, Md.

1.1 ON THE DEVELOPMENT AND APPLICATION OF A EULERIAN ACID DEPOSITION MODEL. Julius S. Chang, National Center for Atmospheric Research (NCAR), Boulder, Colo. (Invited Paper)

1.2 SIMULATIONS OF AN ACID DEPOSITION EPISODE WITH A COMPREHENSIVE LONG-RANGE TRANSPORT MODEL. Akula Venkatram, et al., Environmental Research and Tech., Inc (ERT), Newbury Park, Calif. (Invited Paper)

1.3 BASIC PROBLEMS AND FUTURE SOLUTIONS IN MODELING PHOTOCHEMICAL AIR POLLUTION OVER LARGE TIME AND SPACE DOMAIN. Robert G. Lamb, U. S. Environmental Protection Agency (EPA), Research Triangle Park (RTP), N.C. (Invited Paper)

\section{9:35 AM}

\section{SESSION PI: SUMMARY OF FIRST POSTER SESSION}

Chairperson: Carmen J. Nappo, National Oceanic and Atmospheric Administration (NOAA), Oak Ridge National Lab., Oak Ridge, Tenn.

PI.1 UNCERTAINTY IN SHORT RANGE CALCULATIONS OF AIR-PARCEL TRAJECTORIES. Carmen J. Nappo, NOAA, Oak Ridge National Lab., Oak Ridge, Tenn.; and Michael A. Fosberg, Forest Service, USDA, Riverside, Calif.

PI.2 POLLUTANT TRANSPORT DURING SEA BREEZE CONDITIONS. Marshall A. Atwater, TRC Environmental Consultants, Inc., E. Hartford; and Joseph P. Pandolfo, Center for the Environment and Man, Inc., W. Hartford, Conn.

PI.3 EPISODIC COINCIDENT AIR QUALITY AND PRECIPITATION MEASUREMENTS IN AN URBAN SETTING. Aristidos N. Patrinos, Brookhaven National Lab., Upton, N.Y.; and Francis S. Binkowski, EPA, Research Triangle Park (RTP), N.C.

PI.4 ON THE AERODYNAMIC CHARACTERISTICS OF A FOREST CANOPY. Aloysius K. Lo, Atmospheric Environment Service (AES), Toronto, Ont., Canada

P1.5 CLASSIFYING METEOROLOGICAL CONDITIONS TO OBTAIN EMPIRICAL PREDICTORS OF OZONE EXCEEDANCES. Till E. Stoeckenius and Anthony D. Thrall, Systems Applications, Inc. San Rafael, Calif.

P1.6 HYBRID RECEPTOR MODELING. Charles W. Lewis and Robert K. Stevens, EPA, RTP, N.C.

PI.7 MODEL CITIES PROGRAM: AN INEXPENSIVE AND ACCURATE METHOD FOR MODELING LARGE NUMBERS OF SOURCES IN URBAN AREAS. Christopher Maxwell, Martin Marietta Environmental Systems, Columbia, Md.

PI.8 THEORETICAL ESTIMATION OF URBAN MORNING MIXING HEIGHT. B. Satyanarayana, Andhra Univ., Waltair, India

P1.9 TRAJECTORY UNCERTAINTY IN LONGE-RANGE DISPERSION ESTIMATES. Brian D. Murphy, Oak Ridge National Lab., Oak Ridge, Tenn. 
TUES NOV 18

10:05 AM

10:30 AM

12:05 AM

$1: 30$ PM
SESSION PI: SUMMARY OF FIRST POSTER SESSION (continued)

P1.10 A SENSITIVITY ANAL YSIS OF RELMAP INVOL VING FINE AND COARSE PARTICULATE MATTER. Brian K. Eder, EPA, RTP, N.C.

P1.11 USE OF A NUMERICAL NESTED-GRID MODEL WITH FOURDIMENSIONAL DATA ASSIMILATION FOR SIMULATION OF THE MESOBETA-SCALE OVER COMPLEX TERRAIN. Nelson L. Seaman, David R. Stauffer, Hai-Ru Chang and Thomas T. Warner, Pennsylvania State Univ., University Park, Pa.

PI.12 DETERMINATION OF RATE CONSTANTS USING ATMOSPHERIC CHEMISTRY MODELING. Harish G. Rao, Environmental Engineering Consultant; and Ashok Kumar and Suzane T. Thomas, Univ. of Toledo, Toledo, Ohio

COFFEE BREAK

SESSION 2: EVALUATION OF REGIONAL-SCALE MODELS

Chairpersons: Vince Mirabella, So. Calif. Edison Co., Rosemead, Calif.; and Ted G. Russell, Carnegie-Mellon Univ., Pittsburgh, Pa.

2.1 THE USE OF SPATIAL PATTERNS AND THEIR UNCERTAINTY ESTIMATES IN THE MODEL EVALUATION PROCESS. Robin L. Dennis, EPA; and Steven K. Seilkop, Analytical Sciences Inc., RTP, N.C.

2.2 UNCERTAINTY ESTIMATES FOR REGIONAL MODELS. Richard H. Ball, US Dept. of Energy, Washington, D.C.; Michael Lazaro and Phyllis Fuja, Argonne National Lab. (ANL), Argonne, III.

2.3 QUALIFICATION OF INTER POLATION ERRORS IN TRAJECTORY CALCULATIONS. Jonathan Kahl and Perry Samson, Univ. of Michigan, Ann Arbor, Mich.

2.4 EVALUATION OF SHORT-TERM LONG-RANGE TRANSPORT MODELS. Anthony J. Policastro, et al., ANL, Argonne, Ill.

2.5 EVALUATION OF REGIONAL SULFUR DEPOSITION MODELS. Terry L. Clark, EPA, RTP, N.C.; Eva C. Voldner and Marvin P. Olson, AES, Downsview, Ont., Canada

EVALUATING O3 PREDICTIONS FROM A TEST APPLICATION OF THE EPA REGIONAL OXIDANT MODEL. Kenneth L. Schere, EPA, RTP, N.C.

\section{LUNCH BREAK}

SESSION 3: EVALUATION OF REGIONAL-SCALE TRAJECTORY TECHNIQUES

Chairpersons: Perry, Samson, Univ. of Michigan, Ann Arbor, Mich. and Gordon Beals, Consolidated Edison, New York, N.Y.

3.1 RESULTS OF THE CAPTEX MODEL EVALUATION WORKSHOP. Jack D. Shannon, Anthony J. Policastro and Barry M. Lesht, ANL, Argonne, Ill.

3.2 LONG-RANGE TRANSPORT MODEL EVALUATION USING CAPTEX AIRCRAFT AND SURFACE DATA. Barbara J. Billman Stunder and Jerome L. Heffter, NOAA, Silver Spring, Md.

3.3 A COMPARISON OF MESO-ALPHA MLAN MODEL RESULTS WITH OBSERVATIONS FROM CAPTEX. William E. Davis, Anthony R. Olson, Brett T. Didier and Dennis W. Damschen, Pacific Nor thwest Lab., Richland, Wash.

3.4 LONG-RANGE TRACER DATA SIMULATIONS USING A FOURDIMENSIONAL DATA ASSIMIL ATION METHOD. Tetsuji Yamada and Chin-Yue Kao, Los Alamos National Lab., Los Alamos, N. Mex. 
TUES NOV 18

3:05 PM

3:30 PM

5:30 PM

WED NOV 19

8:15 AM

SESSION 3: EVALUATION OF REGIONAL-SCALE TRAJECTORY TECHNIQUES (continued)

3.5 A LONG-LIVED BALLOON TRACER OF ATMOSPHERIC MOTION TRACKED BY SATELLITE. Bernard D. Zak, E. W. Lichfield, Hugh W. Church and M. D. Ivey, Sandia National Lab., Albuquerque, N. Mex.

LONG-RANGE TETROON TRACKING WITH LORAN-C TRANSPONDERS. Kirk L. Clawson, C. Ray Dickson, Earl F. Pound and Gene E. Start, NOAA, Idaho Falls, Idaho

\section{COFFEE BREAK}

\section{SESSION 4: ANALYSIS OF REGIONAL-SCALE POLLUTION}

Chairpersons: P. K. Misra, Ontario Ministry of the Environment, Toronto, Ont., Canada; and Howard W. Balentine, Radian Corp., Austin, Tex.

4.1 CHANGING PATTERNS IN ACID RAIN. Peter L Finkelstein, EPA; and Steven K. Seilkop, Analytical Sciences, Inc., R TP, N.C.

4.2 A COMPARISON OF METEOROLOGICAL CONDITIONS AND THE AMOUNT OF GASEOUS POLLUTANTS OBSERVED AT WHITEFACE MOUNTAIN. Ian Cohen and Robert Pratt, SUNY, Albany, N.Y.

4.3 TEMPORAL AND SPATIAL VARIABILITY IN THE ACID DEPOSITION EVEN TS. Philip Galvin, Jai-Yeong Ku, S. T. Rao and Vito Pagnotti, New York State Dept. of Environmental Conservation, Albany, N.Y.

4.4 DEPOSITION OF S AND NOx-N TO THE GREAT LAKES BASIN. Jack D. Shannon, ANL, Argonne, Ill; and Eva C. Voldner, AES, Downsview, Ont., Canada

4.5 TRAJECTORY ANALYSIS OF REGIONAL SULFUR TRANSPORT INTO ROCKY MOUNTAIN NATIONAL PARK, COLORADO. James F. Bresch, Marjorie A. Klitch and Elmar R. Reiter, Colorado State Univ., Ft. Collins, Colo. APPLICATION OF REGIONAL PHOTOCHEMICAL MODELS TO ASSESS RURAL OZONE CONCENTRATIONS. Norman C. Possiel, Robert G. Lamb and Joan H. Novak, EPA, RTP, N.C.

\section{ICEBREAKER (Cash Bar)}

\section{SESSION 5: PHYSICAL AND CHEMICAL PROCESSES FOR REGIONAL MODELS I}

Chairpersons: Leonard K. Peters, Univ. of Kentucky, Lexington, Ky. and Paul R. Harrison, Envirosol, Pasadena, Calif.

5.1 THE SIGNIFICANCE OF SUBGRID SCALE SPATIAL INHOMOGENEITIES OF THE PRECURSOR EMISSIONS FIELD IN REGIONAL AIR POLLUT ION MODELS. Noor V. Gillani, Washington Univ., St. Louis, Mo.

5.2 THE SIMULATION AND USES OF SMOG CHAMBER DATA FOR THE DEVELOPMENT OF CHEMICAL MECHANISMS FOR THE MODELING OF ACID RAIN. William R. Stockwell, Xiao-yan Tang, Sasha Madronich and Jack G. Calvert, NCAR, Boulder, Colo.

5.3 THE CONTRIBUTION OF AQUEOUS-PHASE CHEMICAL REACTIONS TO SULFATE PRODUCTION IN THE NORTHEASTERN U.S.:

PREDICTIONS USING AN EULERIAN MODEL. Chris J. Walcek, NCAR, Boulder, Colo.

5.4 DESIGN AND PRELIMINARY RESULTS OF A PRECIPITATION SCA VENGING MODULE. Carl M. Berkowitz and Bryan S. Scott, Pacific Nor thwest Lab., Richland, Wash.; Chris J. Walcek, NCAR, Boulder, Colo.; and Fred M. Vukovich, Research Triangle Inst., RTP, N.C.

5.5 A SIMPLIFIED STRATIFORM CLOUD/WET CHEMISTRY MODULE FOR REGIONAL MODELS. P. K. Karamchandani, Fred W. Lurmann, Akula Venkatram and J. R. Young, ER T, Newbury Park, Calif. 
WED NOV 19 9:35 AM

\section{SESSION P2: SUMMARY OF SECOND POSTER SESSION}

Chairperson: Carmen J. Nappo, NOAA, Oak Ridge National Lab., Oak Ridge, Tenn.

P2.1 PARAMETERIZATION OF VALLEY-SCALE POLLUTANT DISPERSION DURING THE MORNING TRANSITION PERIOD IN REGIONAL-SCALE DISPERSION MODELS. K. Jerry Allwine and C. David Whiteman, Pacific Northwest Lab., Richland, Wash.

P2.2 EVALUATION OF A SINGLE LAYER TRAJECTORY MODEL USING THE METROPOLITAN TRACER EXPERIMENT (METREX) DATA BASE. Michael K. Atchison, ENSCO, Inc., Indian Harbour Beach, Fla.

P2.3 EXPERIMENTAL AND NUMERICAL STUDY OF TRANSITION FROM AN AIR QUALITY EPISODE TO A CATALINA EDDY IN THE LOS ANGELES BASIN. Michael A. Fosberg, Forest Service, USDA, Riverside, Calf.; James L. McElroy, EPA, Las Vegas, Nev.; and Roger M. Wakimoto, Dept. of Atmospheric Science, Univ. of California, Los Angeles, Calif.

P2.4 LABORATORY OBSERVATIONS OF PLUME DEFORMATIONS IN NEUTRAL FLOW OVER A THREE- DIMENSIONAL HILL. William H. Snyder and Robert E. Lawson, Jr., EPA, RTP, N.C.

P2.5 EVALUATIONS OF METEOROLOGICAL AND AIR QUALITY DATA COLLECTED NEAR A FOREST CLEARING. Douglas M. Leahey and $M$. C. Hansen, Western Research Div. of Bow Valley Resource Services Ltd., Calgary, Alta., Canada

P2.6 A HYBRID STATISTICAL-DISPERSION MODEL FOR ESTIMATING THE CONTRIBUTIONS OF MULTIPLE FUGITIVE DUST SOURCES TO AMBIENT TSP CONCENTRATIONS USING EXIS TING AMBIENT TSP DATA. Kenneth Zankel, et al., Martin Marietta Environmental Systems, Columbia, Md.

P2.7 PARAMETRIC SENSITIVITY ANALYSIS AND THE SEASONAL MONTHLY PERFORMANCE EVALUATION OF A LAGRANGIAN REGIONAL-SCALE ATMOSPHERIC TRANSPORT AND DEPOSITION MODEL. Michael A. Lazaro, et al., ANL, Argonne, Ill.

P2.8 A DESCRIPTION OF THE METEOROLOGICAL AND RANGE SAFETY SUPPORT (MARSS) SYSTEM. Gregory E. Taylor and Richard A. Schumann, ENSCO, Inc., Indian Harbour Beach, Fla.

P2.9 MODELING GAMMA ABSORBED DOSE DUE TO MEANDERING PLUMES. Thomas J. Overcamp, Clemson Univ., Clemson, S.C.

P2.10 TWO-PARTICLE DIFFUSION IN THE INHOMOGENEOUS BOUNDARY LAYER FROM TWO-POINT EULERIAN SPACE-TIME STATISTICS. Ronald E. Meyers, White Sands Missile Range, N. Mex.; Richard T. Ceder wall, Lawrence Livermore National Lab., Livermore, Calif.; and William D. Ohmstede, CCM, Las Cruces, N. Mex.

P2.11 GRAPHICAL COMPARISONS FOR DIAGNOSTIC EVALUATION OF MODEL PERFORMANCE. William M. Cox, Joseph A. Tikvart and Gerald K. Moss, EPA, RTP, N.C.
10:05 AM

10:30 AM

\section{COFFEE BREAK}

\section{SESSION 6: PHYSICAL AND CHEMICAL PROCESSES FOR REGIONAL MODELS II}

Chairpersons: Marvin L. Wesely, ANL, Argonne, Ill.; and Nels S. Laulainen, Pacific Nor thwest Lab., Richland, Wash.

6.1 GENERATION OF METEOROLOGICAL DATA FIELDS FOR THE ADOM EULERIAN REGIONAL MODEL. M. Trevor Scholtz, Boris Weisman, The MEP Company, Ont., Canada; Lawrence Mahrt, Oregon State Univ., Corallis, Ore.; and Alistair D. Christie, AES, Downsview, Ont., Canada 
6.2 BOUNDARY LAYER WIND RELATIONSHIPS FOR USE IN A LAGR ANGIAN TRAJECTOR Y MODEL. Suzanne Viessman and Sethu Raman, North Carolina State Univ., Raleigh, N.C.

6.3 BUILDING A POLLUTANT RESER VOIR ALOFT BY CUMULUS CLOUDS. Jason K. S. Ching, EPA, RTP, N.C.

6.4 THE USE OF NUMERICAL SIMULATION TO ASSESS DRY DEPOSITION VELOCITIES FOR SULFUR DIOXIDE. Raymond W. Arritt, Moti Segal and Roger A. Pielke, Colorado State Univ., Ft. Collins, Colo.

6.5 WIDE AREA OZONE DRY DEPOSITION MEASUREMENTS. James M. Godowitch and Jason K. S. Ching, EPA, RTP, N.C.

DESIGN AND APPLICATION OF A COMPREHENSIVE DRY DEPOSIT ION MODEL. Jonathan E. Pleim, ERT, Concord, Mass.; and Akula Venkatram, ER T, Newbury Park, Calif.

12:05 PM

1:30 PM

3:05 PM

3:30 PM

LUNCH BREAK

\section{SESSION 7: MESOSCALE MODELS AND PROCESSES}

Chairpersons: Walter A. Lyons, $R^{*}$ SCAN Corp., Minneapolis, Minn. and John A. Ritter, NASA Langley Research Center, Hampton, Va.

7.1 DECADE OF EXPERIENCE IN PHOTOCHEMICAL GRID MODELING: SYNTHESIS OF US AND EUROPEAN MODEL EVALUATION STUDIES. Thomas W. Tesche and Williams Rogers Oliver, Radian Corp., Sacramento, Calif.

7.2 EVALUATION OF LINKED EULERIAN PBL AND DISPERSION MODELS FOR NYC. Robert Bornstein et. al., San Jose State Univ., San Jose, Calif.

7.3 MEASURED INFLUENCE OF THE NOCTURNAL URBAN HEAT ISLAND ON POLLUTANT TRANSPORT. Roland R. Draxler, NOAA, Silver Spring, Md.

7.4 AN ANALYSIS OF SEVER AL COASTAL DISPERSION MODELS. Mark Stunder, GEOMET Technologies, Inc., Germantown, Md.; Sethu Raman, Nor th Carolina State Univ., Raleigh; and Russell Lee, EPA, RTP, N.C.

7.5 AIRBORNE LIDAR OBSER VATIONS OF POLLUTANT TRANSPORT AND BOUNDARY LAYER STRUCTURE IN A COMPLEX COASTAL ENVIRONMENT. James L. McElroy, EPA, Las Vegas, Nev.; and Ted B. Smith, California Inst. of Tech., Pasadena, Calif.

7.6 THE CATALINA EDDY: AN EFFECTIVE REMOVER OF POLLUTANTS OVER LOS ANGELES. Roger M. Wakimoto, Kevin Durkee and Daniel Landau, Univ. of California, Los Angeles, Calif.

\section{COFFEE BREAK}

\section{SESSION 8: REGULATORY APPLICATIONS}

Chairpersons: Mark L. Kramer, Meteorological Evaluation Services, Inc., Amityville, N.Y.; and Julian C.T. Blomley, Middle South Services, Inc., New Orleans, La.

8.1 EXPERIENCE WITH SOURCE-SPECIFIC MODEL EVALUATION FOR REGULATORY APPLICATIONS. Dean A. Wilson, Joseph A. Tikvart and William M. Cox, EPA, RTP, N.C.

8.2 IMPACT OF REVISIONS TO REGULATORY AIR QUALITY MODELS. Russell F. Lee, Jerr B. Mersch and James L. Dicke, EPA, RTP, N.C.

8.3 URBAN DISPERSION MODEL EVALUATION. Douglas R. Murray, Wayne F. Rostek Jr., David H. Mitchell and Norman E. Bowne, TRC

Environmental Consul tants, Inc. E. Hartford, Conn. 
WED NOV 19

$6: 30 \mathrm{PM}$

7:30 PM

THURS NOV 20

8:15 AM
SESSION 8: REGULATORY APPLICATIONS (continued)

8.4 EVALUATION OF THE EPRI PLUME MODEL FOR TALL STACKS. Steven R. Hanna, Sigma Research Corp., Lexington; and Robert J. Paine, ER T, Concord, Mass.; and Jeffrey C. Weil, Martin Marietta Lab., Baltimore, Md.

8.5 A REVIEW OF THE JOINT INTER AGENCY MODELING STUDY (JIMS) IN THE SOUTHER N CALIFORNIA OCS REGION. Jay L. Haney and David R. Souten, Systems Applications, Inc., San Rafael, Calif.

8.6 EVALUATION OF PREDICTED HYDROCARBONS TO OXIDES OF NITROGEN RATIOS IN OZONE MODELING FOR EMISSION CONTROL STRATEGY DEVELOPMENT. Kit K. Wagner and Bart E. Croes, California Air Resources Board, Sacramento, Calif.

COCKTAIL HOUR

BANQUET

SESSION 9: COMPLEX TERRAIN MODELS/FIELD STUDIES I

Chairpersons: Francis A. Schiermeier, EPA, RTP, N.C.; and Mark Carney, TRC Environmental Consultants, E. Hartford, Conn.

9.1 A SIMPLE TECHNIQUE FOR STACK DESIGN IN COMPLEX TERRAIN. Richard D. Rowe and I. Tas, Univ. of Calgary, Calgary, Alta., Canada

9.2 THE FULL SCALE PLUME STUDY: A SUMMARY OF DATA COLLECTED AND PHENOMENA OBSERVED. Thomas F. Lavery, Sigma Research Corp., Lexington, Mass.

9.3 AN EVALUATION OF THE COMPLEX TERRAIN DISPERSION MODEL AGAINST LABORATOR Y OBSER VATIONS: NEU TRAL FLOWS OVER 2-D AND 3-D HILLS. David G. Strimaitis, Sigma Research Corp., Lexington, Mass.; and William H. Snyder, EPA, RTP, N.C.

9.4 A COMPARISON OF COMPLEX TERR AIN MODELS USING THE FULL SCALE PLUME STUDY (FSPS) DATABASE: COMPLEX I, RTDM, AMD CTDM. Donald C. DiCristofaro, Sigma Research Corp., Lexington; and Bruce A. Egan, ERT, Concord, Mass.

9.5 A NUMERICAL MODEL TO SIMULATE THE ATMOSPHERIC TR ANSPOR T AND DIFFUSION OF POLLUTANTS OVER COMPLEX TERR AIN. Paul J. Dawson, David E. Stock and Brian Lamb, Washington State Univ., Pullman, Wash.

9:35 AM

SESSION P3: SUMMARY OF THIRD POSTER SESSION

Chairperson: Carmen J. Nappo, NOAA, Oak Ridge National Lab., Oak Ridge, Tenn.

P3.1 PRELIMINARY RESULTS FROM THE STABLE ATMOSPHERIC BOUND AR Y LAYER EXPER IMENT (STABLE). Allen $\mathrm{H}$. Weber, Robert J. Kurzeja and R. P. Addis, Savannah River Lab. Aiken, S.C.

P3.2 DISPERSION CLIMATOLOGY AT PORT HOPE, ONTARIO.P. Chen, AES, Toronto, Ont., Canada

P3.3 MOBILE MEASUREMENT OF AN ATMOSPHERIC TRACER. Robert C. Milham, Allen H. Weber and Raymond A. Sigg, Savannah River Lab., Aiken, S.C.

P3.4 DEVELOPMENT AND APPLICATION OF A NESTED GRID MESOSCALE MODEL FOR TRANSPORT AND DIFFUSION OVER COMPLEX TERRAIN. Tetsuj i Yamada and Susan S. Bunker, Los Alamos National Lab., Los Alamos, N. Mex.

P3.5 PHOTODISSOCIATION RATE COEFFICIENTS FOR ATMOSPHERIC CHEMISTR Y MODELS. Sasha Madronich, William R. Stockwell, Darlene M. Steward and Jack G. Calvert, NCAR, Boulder, Colo. 
THURS NOV 20

10:05 AM

$10: 30 \mathrm{AM}$
SESSION P3: SUMMARY OF THIRD POSTER SESSION (continued)

P3.6 LAGR ANGIAN MONTE-CARLO SIMULATION OF MEAN TRACER CONCENTRATION FIELDS DOWNWIND FROM A CIR CULAR LINE SOURCE INSIDE AN ALFALFA CANOPY AND ITS EXPERIMENTAL CONFIRMATION. Monique Y. Leclerc and G. W. Thurtell, Univ. of Guelph, Guelph, Ont., Canada

P3.7 A COMPARISON AND CONTR AST BETWEEN THE PREDICTED RESULTS OF MESO-SCALE MODELING OF FOREST FIRES AND ANTHROPOGENIC IMPACTS FOR NORTHERN CALIFORNIA. Jeffrey A. Panek, Robert D. Sholl and Kennan M. Zishka, Burns \& McDonnell Engineering Company, Kansas City, Mo.

P3.8 SOME ASPECTS OF AIR POLLUTION METEOROLOGY FOR VISAKHAPATNAM-A COASTAL CITY. K. S. Sarma, P. V. Rao and K. P. R. Vittal Murty, Andhra Univ., Waltair, India

P3.9 INPUFF, A MULTIPLE SOURCE PUFF MODEL. William B. Petersen, EPA, RTP, N.C.

P3.10 MODELING OF EXTERNAL RADIATION DUE TO THE TRANSPOR T OF RADIONUCLIDES ACROSS A CANYON. Brent M. Bowen, William A. Olsen, Donald M. VanEtten and Anita I. Chen, Los Alamos National Lab., Los Alamos, N. Mex.

P3.1 1 AN ATMOSPHERIC TR ACER STUDY OF WOOD SMOKE TR ANSPOR T AND DIFFUSION IN A RESIDENTIAL AREA. Tom Ferrara and Brian Lamb, Washington State Univ. Pullman, Wash.

\section{COFFEE BREAK}

SESSION 10: COMPLEX TERRAIN MODELS/FIELD STUDIES II

Chairpersons: Sumner Barr, Los Alamos National Lab., Los Alamos, N. Mex.; and Peter Finkelstein, EPA, RTP, N.C.

10.1 MODEL SIMULATION OF PLUME DISPERSION IN A NARROW VALLEY AFTER SUNRISE. David C. Bader and C. David Whiteman, Pacific Northwest Lab., Richland, Wash.

10.2 THE EXTENSION OF COMPLEX TERRAIN EFFECTS OFFSHORE DURING ONSHORE FLOW. Timothy C. Spangler, Northern Illinois Univ., DeKalb, Ill.

10.3 FLOW CHARACTERIZATION IN THE LEE OF A NEARBY RIDGE USING A MONOSTATIC DOPPLER ACOUSTIC RADAR. R. Leland Davis, Peter D. Pohlot, Galson Technical Services, Inc., E. Syracuse; and Donald Elmendorf, Henningson, Durham and Richardson, Inc., White Plains, N.Y.

10.4 EVALUATION OF A SURFACE-LAYER WINDFLOW MODEL FOR COMPLEX TERRAIN USING METEOROLOGICAL TOWER DATA FROM VANDENBERG AFB, CALIFORNIA. John M. Lanicci, Hanscom AFB, Mass; and Harald Weber, Traben-Trarbach, Federal Republic of Germany

10.5 TRANSPOR T AND DISPERSION OF AIR POLLUTANTS IN A SLOPE WIND AREA. P. Filliger and $\mathrm{H}$. Wanner, Univ. of Berne, Berne, Switzerland.

10.6 STREAMLINES IN STRATIFIED FLOW OVER A THREE-DIMENSIONAL HILL. Roger S. Thompson, EPA; and Michael S. Shipman, Nor throp Services, Inc., R TP, N.C. 
THURS NOV 20 $1: 30$ PM

3:05 PM

3:30 PM

\section{SESSION 11: TOXIC CHEMICAL RELEASES AND RISK ASSESSMENT I}

Chairpersons: Joseph Laznow, Enviroplan, Inc., and William M. Vaughan, Aerovironment, Inc., St. Louis, Mo.

11.1 ASSESSMENT OF A TMOSPHERICALLY-RELEASED RADIONUCLIDES USING THE COMPUTERIZED RADIOLOGICAL RISK INVESTIGATION SYSTEM. Christopher B. Nelson, EPA, Washington, D.C ; Andrea L. Sjoreen, Charles W. Miller and C. F. Baes III, Oak Ridge National Lab., Oak Ridge, Tenn.

11.2 HUMAN EXPOSURE ESTIMATES USING GUIDELINE MODELS: AN INTEGR ATED APPROACH. George J. Schewe and Joseph Carvitti, PEI Associates, Inc., Cincinnati, Ohio

11.3 CASE STUDIES OF VERTICAL WIND SHEAR AND ITS IMPLICATIONS FOR PLUME TR ANSPOR T ESTIMATIONS FOR EMERGENCY RESPONSE PLANNING. Robert J. Goodwin, Doyle E. Pittman and Norris A. Nielsen, Tennessee Valley Authority, Muscle Shoals, Ala.

11.4 DETERMINING THE IMPACT OF AN ACCIDENTAL HAZARDOUS CHEMICAL RELEASE. Alex Kasprak, Stephen A. Vigeant and Gregory W. McBride, Stone and Webster Engineering Corp., Boston, Mass.

11.5 ARMY MODEL OF ATMOSPHERIC CHEMICAL HAZ ARDS (MACH 1). Ronald E. Meyers, Larry R. James, White Sands Missile Range, N. Mex.; and Joseph H. Shinn, Lawrence Livermore National Lab., Livermore, Calif.

11.6 AN ANALYSIS OF ATMOSPHERIC DISPERSION OF TOXIC CONTAMINANTS RESULTING FROM A SPILL OF A HIGHLY REACTIVE

ACID. David M. Shea and Robert G. McInnes, ER T, Concord, Mass.

COFFEE BREAK

\section{SESSION 12: TOXIC CHEMICAL RELEASES AND RISK ASSESSMENT II.}

Chairpersons: Robert C. Beebe, Tennessee Valley Authority (TVA); and Raymond DeLand, Ray DeLand and Assoc., Ossining, N.Y.

12.1 ASSESSING THE RELIABILITY OF DISPERSION MODELS FOR HAZARDOUS MATERIALS RELEASES. David E. Layland, EPA, RTP, N.C.

12.2 EVALUATION OF THE AIR TOX EVAPOR ATION AND DISPERSION ALGORITHMS USING DATA FROM HEAVY GAS FIELD EXPERIMENTS. David W. Heinold, Robert J. Paine and Douglas G. Smith, ERT, Concord, Mass.

12.3 TECHNIQUES FOR EVALUATING ENVIRONMENTAL RISKS OF SOUR GAS DEVELOPMENT. D. Howard Gebhart and Mary-Jo Caldwell, ER T, Ft. Collins, Colo.

12.4 HYPERGOLIC ACCIDENTAL RELEASE MODEL (HARM). Lawrence E. Key, Air Force Engineering and Service Center, Tyndall AFB, Fla.; and Clinton R. Bowman, Jr., H. E. Cramer, Inc., Salt Lake City, Utah

12.5 CONSEQUENCE MODELING OF ACCIDENTAL RELEASES DURING TR ANSPOR TATION, HANDLING AND STOR AGE OF LIQUID HAZARDOUS W ASTES. Michael J. Barboza, Louis M. Militana and Neil M. Haymes, Woodward-Clyde Consultants, Wayne, N.J. AND MISSILE RANGES. Billie F. Boyd, Eastern Space and Missile Range Center, Patrick AFB, Fla.; and Clinton R. Bowman, H. E. Cramer, Inc., Salt Lake City, Utah 
FRI NOV 21

$8: 15$ AM

\section{SESSION 13: ADVANCES IN DISPERSION TECHNIQUES I}

Chairpersons: William Porch, Lawrence Livermore Lab., Livermore Calif.; and S. T. Rao, New York State Dept. of Environmental Conservation, Albany, N.Y.

13.1 STATISTICAL EVALUATION OF INTEGR AL AND REGULATORY PLUME RISE ALGROITHMS. Ronald L. Petersen, Cermak Peterka \& Assoc., Inc., Ft. Collins, Colo.

13.2 EVALUATION OF PLUME RISE ESTIMATION METHODS AT THE EPA'S FULL SCALE PLUME STUDY SITE. Robert J. Paine and Elizabeth M. Insley, ER T, Concord, Mass.; and Waynn L. Eberhard, NOAA, Boulder, Colo.

13.3 DISPERSION OF BUOYANT STACK PLUMES IN A CONVECTIVE BOUNDAR Y LAYER. Glen E. Willis, Oregon State Univ., Corvallis, Ore.

13.4 ESTIMATING SURFACE CONCENTR ATIONS FROM A BUOYANT PLUME IN THE CONVECTIVE BOUNDAR Y LAYER. TOM E. Pierce, EPA, RTP, N.C.

13.5 DISPERSION OF BUOYANT PLUMES IN THE CONVECTIVE BOUNDARY LAYER. Jeffrey C. Weil, Martin Marietta Lab., Baltimore; Louis A. Corio and Roger P. Brower, Martin Marietta Lab, Columbia, Md.

13.6 SOME COMPARISONS OF CONVECTIVE DIFFUSION FIELD MEASUREMEN TS WITH LABORATORY AND NUMERICAL EXPER IMENTS. Gary A. Briggs, EPA, RTP, N.C ; Wynn L. Eberhard, William R. Moninger and John E. Gaynor, NOAA, Boulder, Colo.

9:45 AM

10:10 AM

\section{COFFEE BREAK}

\section{SESSION 14: ADVANCES IN DISPERSION TECHNIQUES II}

Chairpersons: Ramesh Godbole, Potomac Electric Power Co., Washington, D.C.; and Bruce Pringle, Army Pollution Abatement Program, Aberdeen, Md.

14.1 A LOOK AT THE INFLUENCE OF BUILDING ORIENTATION ON PLUME DISPERSION IN THE WAKE OF A BUILDING. Alan H. Huber, EPA, RTP, N.C.

14.2 APPLICATION OF EXPONENTIAL-SUM FITTING IN AN ANALYSIS OF INTEGRAL TIME SCALES FROM MEASUREMEN TS IN FLAT AND COMPLEX TERRAIN. Da-hai Xu, Academy of Meteorological Sciences, Beijing, People's Republic of China; and Steven G. Perry and Peter L. Finkelstein, EPA, RTP, N.C.

14.3 A THEORETICAL ANALYSIS OF THE PLUME DISPERSION PARAMETER SIGMA Z. Brian Henderson-Sellers, Univ. of Salford, Salford, England

14.4 A HORIZONTAL FLUX TECHNIQUE FOR TR ACE GAS SOURCE AT TR IBUTION. Kenneth E. Pickering and Joshua Z. Holland, Univ. of Maryland, College Park, Md.

14.5 A NONSTEADY-STATE ADAPTIVE VOLUME PLUME MODEL SUITABLE FOR REGIONS OF STRONG VERTICAL GR ADIENTS OF WIND AND STABILITY. Frank L. Ludwig, SRI International, Menlo Park; Rosa Salvador and Robert Bornstein, San Jose State Univ., San Jose, Calif. 

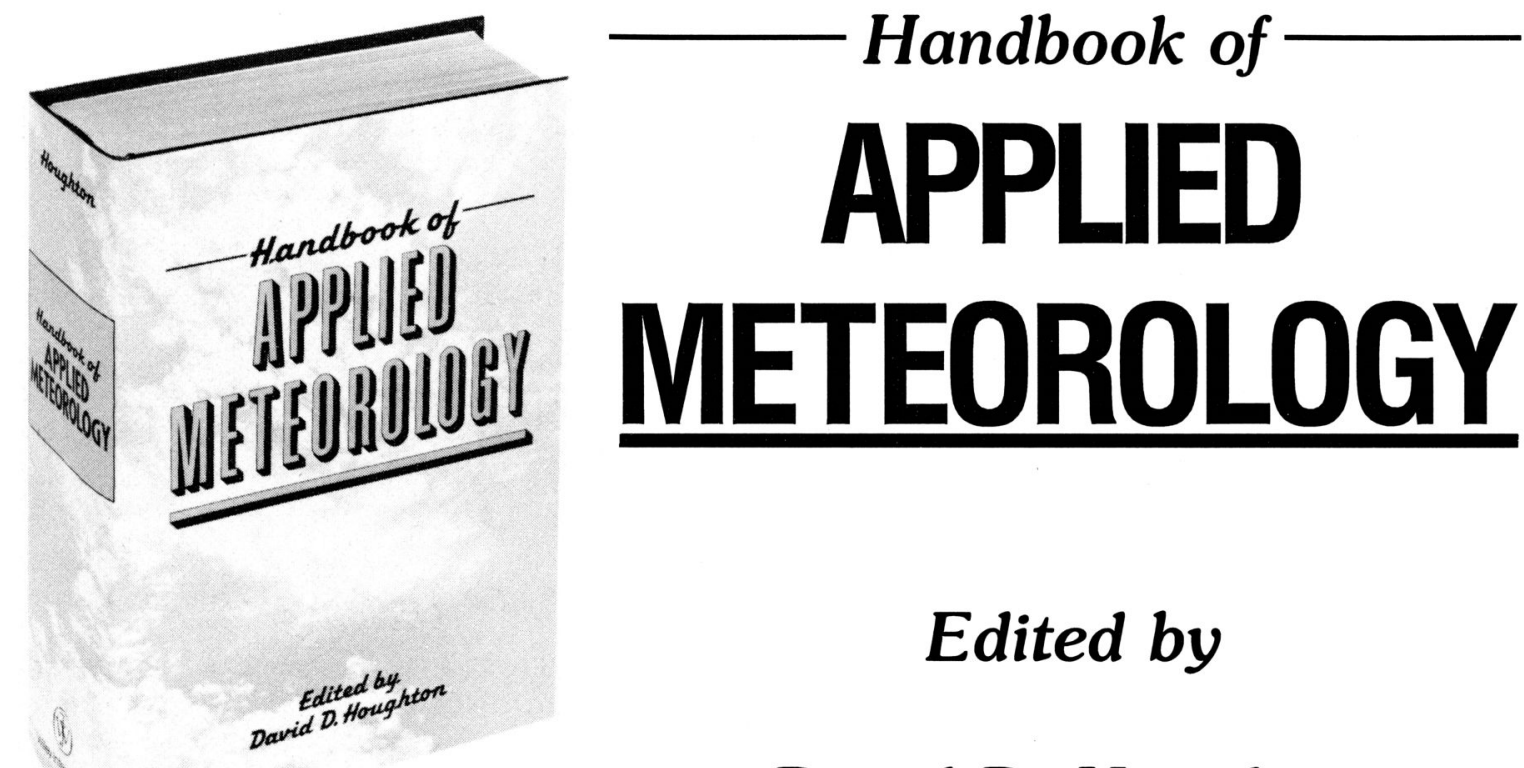

\section{Edited by}

David D. Houghton

The 46 chapters in the Handbook of Applied Meteorology are organized into five main sections: Part 1 deals with fundamental meteorological information; Part 2 addresses the topic of measurements; Part 3 focuses on specific major applications of meteorology; Part 4 provides a general discussion on some major impacts of meteorology on society; and Part 5 summarizes a wide range of resources available for meteorological data and knowledge. Two appendixes give additional information on terminology, units, and climatic data. This handbook presents, for the first time, an authoritative, comprehensive reference on meteorological knowledge and technology. Designed for professionals and technicians both within and outside the meteorological profession, this broad-ranging book offers general guidelines for those who need information on the effects of weather.

The Handbook of Applied Meteorology was awarded honorable mention in the category for best physical science book of 1985 in the Tenth Annual Professional and Scholarly Book Awards sponsored by the Association of American Publishers.

To order please send $\$ 84.95$ plus $\$ 2.00$ postage and handling to

\section{AMERICAN METEOROLOGICAL SOCIETY 45 BEACON ST. BOSTON, MA 02108}


PROGRAM

SECOND INTERNATIONAL CONFERENCE ON SOUTHERN HEMISPHERE METEOROLOGY, DECEMBER 1-5, 1986, WELLINGTON, NEW ZEALAND

AMS NATIONAL OFFICERS

1986 AMS COMMITTEE ON THE SOUTHERN HEMISPHERE

PROGRAM COMMITTEE

NEW ZEALAND LOCAL ORGANIZING COMMITTEE

\section{SYNOPSIS OF SESSIONS}

President: Joseph Smagorinsky

President-Elect: Albert J. Kaehn, Jr. Executive Director: Kenneth C. Spengler
Kevin E. Trenberth, Chmn.

John W. Kidson

Vernon Kousky

Kevin E. Trenberth, Chmn. Douglas J. Gauntlett Eugenia Kalnay John W. Kidson

John W. Kidson, Chmn. John F. deLisle
Harry van Loon

Carlos R. Mechoso

Kingtse C. Mo

Vernon Kousky

Alex A. Neale

Mario Nunez

A. Brett Mullan

Alex A. Neale
Neville Nicholls Mario Nunez

Julia N. Paegle Harry van Loon Peter J. Webster

J. Tom Steiner

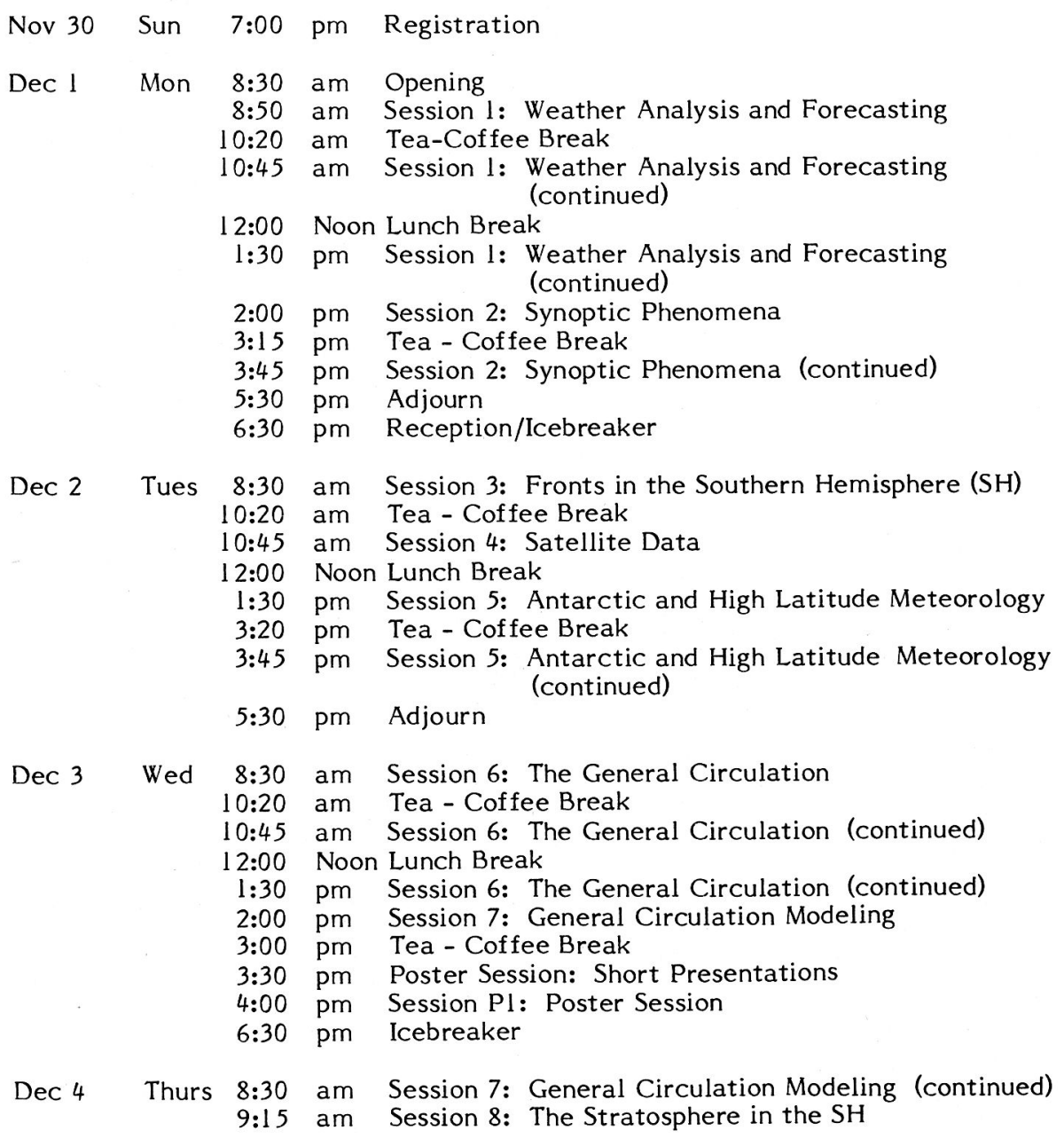


SYNOPSIS OF SESSIONS (continued)

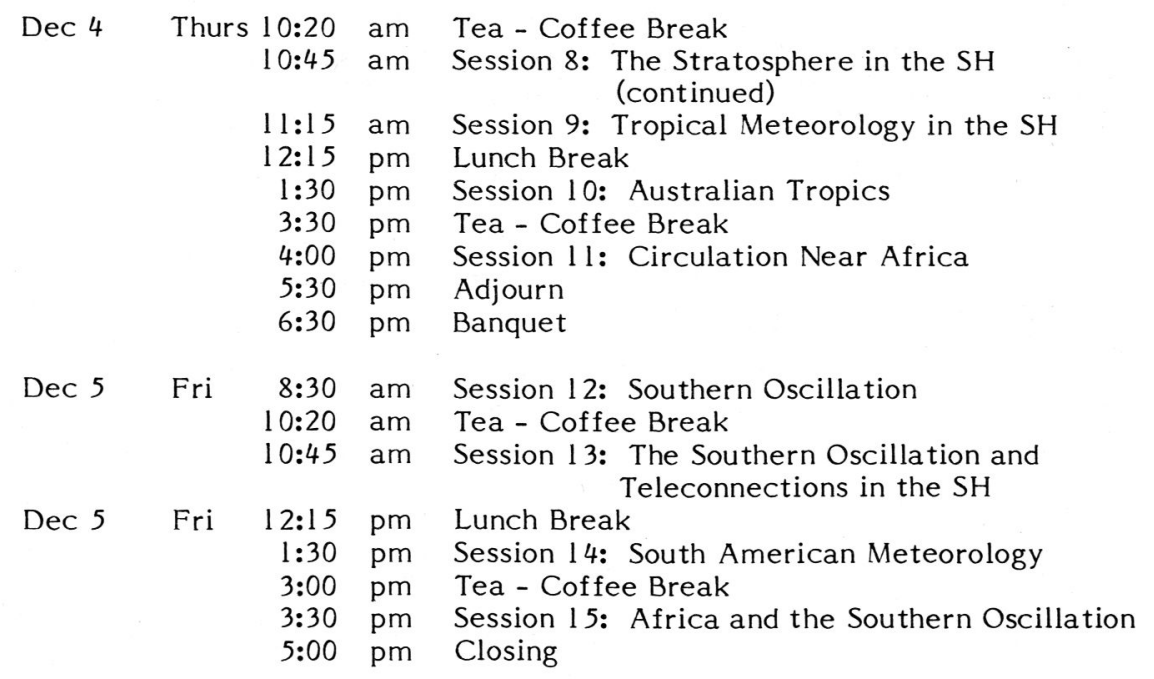

GENERAL INFORMATION

ACCOMMODATIONS

REGISTRATION

FUNCTIONS

TRAVEL

CLIMATE

FINANCIAL

TOURS

CONFERENCE

ORGANIZERS

PROGRAM NOTES
The Second International Conference on Southern Hemisphere Meteorology will be held 1-5 December 1986 in the "Academy" Conference and Hotel Centre, Wellington, New Zealand. The conference is sponsored by the American Meteorological Society, the New Zealand Meteorological Service, Meteorological Society of New Zealand and World Meteorological Organization.

All sessions will be held at the "Academy" Conference Centre in Wellington. The centre includes bars, restaurant, swimming pool and other recreation facilities. Room rates are expected to be about US $\$ 45$ per day. Reservations should be made through the conference organizers (see below).

The conference desk will be open Sunday evening 30 November. The registration fee will be approximately US\$150. A preprint volume will be included within the cost of the registration fee and will be available at time of registration.

The program includes a welcoming function, banquet and icebreaker. A local excursion is planned for the Saturday following the conference and there will be an opportunity to view the work of the New Zealand Meteorological Office.

New Zealand's main international airport in Auckland is connected by frequent flights to Wellington, the hub of the domestic network. Wellington airport also provides connections to Australia and is 15 minutes by car from the city centre. Intending participants should check with their travel agent regarding visa requirements. Visas are not required for short visits by citizens of Australia, Canada, USA, United Kingdom, Japan and most western European countries.

December is early summer in Wellington with average daytime temperatures near $20 \mathrm{C}$ and nighttime temperatures around 12C. Windy conditions are not uncommon at this time of year.

The New Zealand dollar is presently (July, 1986) worth around US\$.57. Major credit cards are accepted by a large proportion of restaurants, shops and hotels.

A wide variety of tours will be available both before and after the conference to view New Zealand's many scenic attractions and take part in various activities of interest to visitors. These will be arranged on an individual basis. For further information on the options available please send inquiries to the conference organizers.

Conference Consultants and Management, P. O. Box 11257 Wellington New Zealand.

Ten invited papers will be 30 minute presentations. All other oral presentations are planned for 12 minutes plus 3 minutes discussion. Some have been designated as reserve papers. Note that the program is preliminary, owing to uncertainties in availability of travel funds. 
PROGRAM

MON DEC 1

8:30 AM

OPENING

Chairperson: Kevin E. Trenberth, National Center for Atmospheric Research (NCAR), Boulder, Colo.

\section{SESSION 1: WEATHER ANALYSIS AND FORECASTING}

1.1 GLOBAL ANALYSIS AND PREDICTION AT WMC WASHINGTON. William D. Bonner, Glen White, Vernon Kousky, M. Steven Tracton and George Cressman, National Meteorological Center (NMC), Washington, D.C. (Invited Paper)

1.2 PROCEDURES AND CONCEPTS USED IN SOUTHERN HEMISPHERE ANALYSES AT WMC MELBOURNE. Leon B. Guymer, Bureau of Meteorology, Melbourne, Vic., Australia (Invited Paper)

1.3 SOUTHERN HEMISPHERE FORECAST SKILL AND ITS VARIABILITY WITH THE NATIONAL METEOROLOGICAL CENTER'S GLOBAL SPECTRAL MODEL. M. Steven Tracton, NMC, Washington, D.C.

1.4 IMPLICATIONS OF TROPICAL UNCERTAINTY ON EXTENDED WEATHER PREDICTION IN THE SOUTHERN HEMISPHERE. Peter J. Webster, Arthur N. Samel and Edward A. O'Lenic, Pennsylvania State Univ., University Park, Pa.

10:20 AM

$10: 45 \mathrm{AM}$
$12: 00$ NOON

$1: 30$ PM
TEA - COFFEE BREAK

\section{SESSION 1: WEATHER ANALYSIS AND FORECASTING (continued)}

Chairperson: John S. Hickman, New Zealand Meteorological Service, Wellington, New Zealand

1.5 TROPICAL NUMERICAL WEATHER PREDICTION STUDIES WITH THE BMRC GLOBAL SPECTRAL MODEL. Kamal Puri and Noel Davidson, Bureau of Meteorology Research Centre (BMRC), Melbourne, Vic., Australia

1.6 LIMITED AREA NUMERICAL PREDICTION EXPERIMENTS OVER THE AUSTRALIAN TROPICS. Noel Davidson, Kamal Puri and Les Logan, BMRC, Melbourne, Vic., Australia

1.7 IMPLEMENTING A NON-INTERPOLATING SEMI-LAGRANGIAN TIME SCHEME IN THE AUSTRALIAN/NEW ZEALAND REGIONAL P. E. MODEL. Michael J. Revell, New Zealand Meteorological Service, Welling ton, New Zealand

1.8 PAPER WITHDRAWN

1.9 OPERATIONAL INTERACTIVE METEOROLOGICAL ANALYSIS EMPLOYING METEOSAT INFRA-RED IMAGERY. Johan van Heerden, The Weather Bureau, Pretoria, South Africa

\section{LUNCH BREAK}

SESSION 1: WEATHER ANALYSIS AND FORECASTING (continued)

Chairperson: Douglas J. Gauntlett, Bureau of Meteorology, Melbourne, Vic., Australia

1.10 ECMWF FORECAST ERRORS IN SOUTHERN HEMISPHERE WAVE COMPONENTS. Alex A. Neale and A. Brett Mullan, New Zealand Meteorological Service, Wellington, New Zealand

1.11 A TREND IN THE SKILL OF AUSTRALIAN TEMPERATURE FORECASTS. H. Stern, Bureau of Meteorology, Melbourne, Vic., Australia 
MON DEC 1 2:00 PM

3:15 PM

3:45 PM

5:30 PM

6:30 PM

TUES DEC 2 8:30 AM

\section{SESSION 2: SYNOPTIC PHENOMENA}

Chairperson: Douglas J. Gauntlett, Bureau of Meteorology, Melbourne, Vic., Australia

2.1 THE AUSTRALIAN EAST-COAST LOW OF JULY 1984. Amanda Lynch, Lance F. Leslie and Greg J. Holland, BMRC, Melbourne, Vic., Australia

2.2 SUBTROPICAL CYCLOGENESIS OFF THE EAST COAST OF AUSTRALIA. Jeff Callaghan, Bureau of Meteorology, Brisbane, Queensland, Australia

2.3 THE NOR THWEST AUSTR ALIAN CLOUD BAND. Ian D. Bell, Bureau of Meteorology, Melbourne, Vic., Australia

2.4 AN OBSER VATIONAL STUDY OF POLAR AIR DEPRESSIONS IN THE AUSTRALASIAN REGION. August H. Auer, Jr., Univ. of Wyoming, Laramie, Wyo.

TEA - COFFEE BREAK

SESSION 2: SYNOPTIC PHENOMEMA (continued)

Chairperson: Alex A. Neale, New Zealand Meteorological Service, Wellington, New Zealand

2.5 POLAR AIR STREAM CYCLOGENESIS IN THE NEW ZEALAND AREA. Mark R. Sinclair, New Zealand Meteorological Service, Wellington, New Zealand

2.6 TROPOSPHERIC CIRCULATION ASSOCIATED WITH A COLD SURGE EVENT DURING THE SOUTHERN HEMISPHERE WINTER IN SOUTH AMERICA. Pao-Shin Chu, Univ. of Hawaii at Manoa, Honolulu, Hawaii

2.7 INTERACTIONS BETWEEN FRONTAL SYSTEMS IN SOUTH AMERICA AND TROPICAL CONVECTION OVER THE AMAZON. Alda S. de Oliveira and Carlos A. Nobre, Inst. de Pesquisas Espaciais (INPE), Sao Jose dos Campos, Brazil

2.8 THE MAY 29-30, 1984, CYCLOGENESIS OVER ARGENTINA CENTRAL PLAINS. Mario N. Nunez and H. H. Ciappesoni, Univ. of Buenos Aires, Buenos Aires, Argentina

2.9 THE ROLE OF LATENT HEAT IN KINETIC ENERGY CONVERSIONS OF SOUTH PACIFIC CYCLONES. Deirdre M. Kann and Dayton G. Vincent, Purdue Univ., W. Lafayette, Ind.

2.10 IMPACT OF TROPICAL LATENT HEAT RELEASE ON THE SUBTROPICAL JET STREAM OF THE SOUTHERN HEMISPHERE. Julia N. Paegle, Univ. of Utah, Salt Lake City, Utah; and Kingtse Mo, Univ. of Maryland, College Park, Md.

ADJOURN

RECEPTION/ICEBREAKER

\section{SESSION 3: FRONTS IN THE SOUTHERN HEMISPHERE}

Chairperson: John Zillman, Bureau of Meteorology, Melbourne, Vic., Australia

3.1 THE AUSTRALIAN SUMMERTIME "COOL CHANGE": THEOR IES AND OBSER VATIONS. Roger K. Smith, Monash Univ., Clayton, Vic., Australia REFERENCE TO AUSTRALIAN SUMMERTIME COLD FRONTS: John R. Garratt, Commonwealth Scientific and Industrial Research Organization (CSIRO), Mordialloc, Vic., Australia 
TUES DEC 2

10:20 AM

10:45 AM

12:00 NOON

$1: 30$ PM
SESSION 3: FRONTS IN THE SOUTHERN HEMISPHERE (continued)

3.3 A NUMERICAL STUDY OF THE I DECEMBER 1982 SOUTHERLY BUSTER EVENT. Peter A. C. Howells, CSIRO, Mordialloc, Vic., Australia

3.4 MESOSCALE NWP OF COLD FRONTS IN SOUTHERN AUSTR ALIA. G. A. Mills, BMRC, Melbourne, Vic., Australia

3.5A STUDY OF SUMMER-TIME COOL CHANGES OVER S.E . AUSTRALIA. Kathleen L. McInnes, Monash Univ., Clayton, Vic., Australia

3.6 THE GENERATION AND EVOLUTION OF DISTURBANCES UPSTREAM OF COLD FRONTS APPROACHING SOUTH-EASTERN AUSTRALIA. Peter G. Baines, CSIRO, Mordialloc, Vic., Australia

3.7 CYCLOGENESIS ALONG FRONTAL ZONES. G. W. Kent Moore and W. R. Peltier, Univ. of Toronto, Toronto, Ont., Canada

TEA - COFFEE BREAK

\section{SESSION 4: SATELLITE DATA}

Chairperson: William D. Bonner, NMC, Washington, D.C.

4.1 EXPERIMENTS ON THE FORECAST IMPACT OF SATELLITE DATA IN THE SOUTHERN HEMISPHERE. Eugenia Kalnay, NASA/Goddard Space Flight Center (GSFC), Greenbelt, Md. (Invited Paper)

4.2 PERSISTENCE AND VARIATIONS OF TYPES OF SPATIAL PATTERNS OF MONTHLY ANOMALOUS OUTGOING LONGWAVE RADIATION IN THE TROPICS AND SUBTROPICS. Jay S. Winston and Stuart M. Fredenreich, Univ. of Maryland, College Park, Md.

4.3 SATELLITE CLOUD CLIMATOLOGY FOR THE SOUTHERN ATLANTIC OCEAN, JULY 1985 TO JUNE 1986. Johan van Heerden, The Weather Bureau, Pretoria, South Africa

4.4 OCEANIC CLOUD--RADIATION FEEDBACKS IN THE SOUTHERN HEMISPHERE. Beth Chertock, Sam Iacobellis and Richard C. J. Somerville, Scripps Institution of Oceanography, La Jolla, Calif.

\section{LUNCH BREAK}

\section{SESSION 5: ANTARCTIC AND HIGH LATITUDE METEOROLOGY}

Chairperson: Neil A. Streten, Bureau of Meteorology, Melbourne, Vic., Australia

5.1 THE SOUTHERN HEMISPHERE CIRCULATION OF ATMOSPHERE, OCEAN AND SEA ICE. William Budd, Univ. of Melbourne, Parkville, Vic., Australia (Invited Paper)

5.2 THE CIR CULATION CHANGES INDUCED BY THE REMOVAL OF ANTARCTIC SEA ICE IN A JULY GENERAL CIRCULATION MODEL. lan Simmonds and Martin Dix, Univ. of Melbourne, Parkville, Vic., Australia

5.3 ATMOSPHERIC GENER AL CIRCULATION MODEL SIMULATIONS OF THE MODERN ANT ARCTIC CLIMATE. Michael E. Schlesinger, Oregon State Univ., Corvallis, Ore.

5.4 EFFECT OF ANTARCTICA ON UPPER LEVEL FLOWS DURING THE 1979 WINTER. Susan Stucki and Julia N. Paegle, Univ. of Utah, Salt Lake City, Utah

5.5 KATABATIC DRAINAGE FLOWS OVER ANTARCTICA AND THE POLAR VORTEX. Ian N. James, Univ. of Reading, Reading, England

5.6 AN APPLICATION OF AUTOMATIC WEATHER STATION DATA TO STUDY OF KATABATIC FLOW IN EAST ANTARCTIC. B. van Meurs and Ian Allison, Univ. of Melbourne, Parkville, Vic., Australia 
TUES DEC 2 3:45 PM

5:30 PM

WED DEC 3 $8: 30$ AM
SESSION 5: ANTARCTIC AND HIGH LATITUDE METEOROLOGY (continued)

Chairperson: William Budd, Univ. of Melbourne, Parkville, Vic., Australia

5.7 SEA ICE AND ATMOSPHERIC CIRCULATION IN THE ROSS SEA AREA, ANT ARCTICA. Andrew P. Sturman and Ian F. Owens, Univ. of Canterbury, Christchurch, New Zealand

5.8 WEATHER AND CLIMATE IN THE VICINITY OF ROSS ISLAND, ANTARCTICA. Michael L. Savage and Charles R. Stearns, Univ. of Wisconsin, Madison, Wis.

5.9 METEOROLOGICAL FACTORS ASSOCIATED WITH THE BESETMENT OF THE M. V. NELLA DAN OFF THE ANTARCTIC COAST, OCTOBER 1985. Jeffrey C. Wilson, Bureau of Meteorology, Melbourne, Vic., Australia

5.10 THE REGIONAL CLIMATE OF TWO ANTARCTIC OASES. Neil A. Streten, Bureau of Meteorology, Melbourne, Vic., Australia

5.11 SNOW DEPTH CLIMATOLOGY FOR ANTARCTICA. William R. Schaub, Jr., USAFETAC, Asheville, N.C.

5.12 CLOUD STUDIES AT SYOW A STATION IN EAST ANTARCTICA BY MEANS OF LASER-RADAR. Makoto Wada, National Inst. of Polar Research, Tokyo; and Yasunobu Iwasaka, Water Research Inst., Nagoya, Japan

5.13 ANNU AL CHANGE OF ATMOSPHERIC OZONE INCLUDING THE POLAR NIGHT SEASON AT SYOWA STATION, ANTARCTICA FROM FEBR UAR Y 1982 TO JANU AR Y 1983. Shigeru Chubachi, Meteorological Research Inst., Ibaraki, Japan

ADJOURN

SESSION 6: THE GENERAL CIRCULATION

Chairperson: John W. Kidson, New Zealand Meteorological Service, Wellington, New Zealand

6.1 THE ROLE OF EDDIES IN MAINTAINING THE DISTRIBUTION OF WESTERLIES IN THE SOUTHERN HEMISPHERE. Kevin E. Trenberth, NCAR, Boulder, Colo. (Invited Paper)

6.2 THE BAROCLINIC STORM TRACK OF THE SOUTHERN HEMISPHERE TROPOSPHERE IN 6 YEARS OF ECMWF DATA. Brian J. Hoskins, Prashant Sardeshmukh and Ian N. James, Univ. of Reading, Reading, England

6.3 ATMOSPHERIC ENERGETICS FOR THE SOUTHERN HEMISPHERE FROM ECMWF DATA. Peter Speth, Univ. of Cologne, Cologne, Federal Republic of Germany

6.4 FLUCTUATIONS IN THE ANGULAR MOMENTUM OF THE SOUTHERN HEMISPHERE TROPOSPHERE AND STRATOSPHERE: DIAGNOSES AND ANALYSIS QUALITY. Richard D. Rosen, Atmospheric and Environmental Research Inc., Cambridge, Mass. ESTIMATES OF SOURCES AND SINKS OF ATMOSPHERIC MOISTURE IN THE SOUTHERN HEMISPHERE. David A. Howarth, Univ. of Louisville, Louisville, Ky.

6.6 A COMPARISON OF SOUTHERN HEMISPHERE CIRCULATION STATISTICS BASED ON GFDL AND AUSTRALIAN ANALYSES. David Karoly, Monash Univ., Clayton, Vic., Australia; and Abraham H. Oort, Princeton Univ., Princeton, N.J. 
6.7 ISENTROPIC HADLEY MASS CIRCULATIONS AND THEIR FOR CING DETERMINED FROM GWE DATA. Donald R. Johnson, Univ. of Wisconsin, Madison, Wis.

6.8 DYNAMIC ASPECTS OF SOUTHERN HEMISPHERE MEDIUM-SCALE W A VES DUR ING THE SUMMER SEASON. Tsing-Chang Chen, Ming-Cheng Yen and Durga P. Nune, lowa State Univ., Ames, Iowa

6.9 THE RELATIONSHIP OF SOUTHERN HEMISPHERE PLANETARY W AVES TO TYPICAL WEATHER REGIMES OF THE SOUTHERN INDIAN AND SOUTHERN PACIFIC OCEANS. A. Brett Mullan, Henry W. Hill and P. W. Dini, New Zealand Meteorological Service, Wellington, New Zealand

6.10 QUASI-STATIONAR Y STATES IN THE SOUTHERN HEMISPHERE. Kingtse C. Mo, Univ. of Maryland, College Park, Md. Kidson, New Zealand Meteorological Service, Wellington, New Zealand

$12: 00$ NOON

$1: 30$ PM

2:00 PM

\section{LUNCH BREAK}

SESSION 6: THE GENERAL CIRCULATION (continued)

Chairperson: Eugenia Kalnay, NASA/GSFC, Greenbelt, Md.

6.12

OBSER VATIONAL MODES OF VACILLATION IN UPPER TROPOSPHERIC ZONALLY AVERAGED GLOBAL ZONAL WINDS DURING WINTER AND SUMMER. Steven W. Lyons, Pacific Missile Test Center, Point Mugu, Calif.

6.13

MULTIPLE WEATHER REGIMES IN THE SOUTHERN HEMISPHERE. Shigeo Yoden, Univ. of Washington, Seattle, Wash.; Masato Shiotani and Isamu Hirota, Geophysical Inst., Kyoto Univ., Kyoto, Japan

RESER VE PAPER FOR SESSION 6:

6.14 FURTHER ANALYSES OF THE $500 \mathrm{MB}$ GEOPOTENTIAL ALONG 5OS: ZONAL TELECONNECTIONS AND LONGITUDE-TIME LAG CORRELATIONS. Klaus Fraedrich and Martin Lutz, Free Univ. of Berlin, Berlin, Federal Republic of Germany

SESSION 7: GENERAL CIRCULATION MODELING

Chairperson: Eugenia Kalnay, NASA/GSFC, Greenbelt, Md.

7.1 INTER ANNUAL VARIATION AND TELECONNECTIONS IN THE SOUTHERN HEMISPHERE SIMULATED BY 12-YEAR RUN OF THE MRI GCM-I. Koji Yamazaki, Tatsushi Tokioka and Akio Kitoh, Meteorological Research Inst., Tsukuba, Ibaraki, Japan ON THE IMPACT OF INTERANNUALLY VARYING OCEAN SURFACE TEMPER ATURES ON THE VARIABILITY OF SOUTHERN HEMISPHERE TIME AVERAGED ATMOSPHERIC STATES. Robert M. Chervin, NCAR, Boulder, Colo.

7.3 THE SIMULATION OF THE SEASONAL CYCLE BY A GENERAL CIR CULATION MODEL AND A COMPARISON TO OBSER VATIONS: SOUTHER N HEMISPHERE PERSPECTIVE. David M. Straus, NASA/GSFC, Greenbelt, Md.

7.4 INTERACTIONS BETWEEN THE TROPICS AND SOUTHERN HEMISPHERE MID-LATITUDES: OBSER VATIONS AND GCM SIMULATIONS WITH PRESENT AND DOUBLED AMOUNTS OF CO2. Gerald A. Meehl, NCAR, Boulder, Colo.

TEA - COFFEE BREAK 
WED DEC 3 3:30 PM

4:00 PM
POSTER SESSION: Short Presentations

Chairperson: Roland A. Madden, NCAR, Boulder, Colo.

SESSION PI: POSTER SESSION

PI.1 THREE DIMENSIONAL AIRFLOWS IN EXTRATROPICAL CYCLONES. Ian D. Bell, Bureau of Meteorology, Melbourne, Vic. Australia

PI.2 SOME INTERACTION BETWEEN ANTARCTICA AND THE ATMOSPHERE CIR CULATION AROUND SOUTH AMERICA. Iracema F. A. Cavalcanti, INPE, Sao Jose dos Campos, Brazil

PI.3 LEE CYCLOGENESIS OF THE ANDES -- ROTATING TANK CIRCULATION. Wen-Dar Chen, Yale Univ., New Haven, Conn.

P1.4 WESTW ARD MOVING DISTURBANCES IN THE SOUTHWEST INDIAN OCEAN. Raphael E. Okoola, Kenya Meteorological Dept., Nairobi, Kenya

PI.5 OROGRAPHIC EFFECTS ON AIRFLOW AROUND NEW ZEALAND. Wolfgang Ulrich and Roger K. Smith, Monash Univ., Clayton, Vic., Australia

PI.6 THE ROLE OF TROPICAL-EXTRATROPICAL INTERACTION IN VICTORIAN WINTER PRECIPITATION. William J. Wright, Melbourne Univ., Parkville, Vic., Australia

PI.7 ON A SIMPLE MODEL FOR COASTALLY TRAPPED FRONTS. Kathleen L. McInnes, Monash Univ., Clayton, Vic., Australia

PI.8 ON THE STRUCTURE OF EXTRA-TROPICAL CYCLONES. G. W. Kent Moore and W. R. Peltier, Univ. of Toronto, Toronto, Ont., Canada

PI.9 A CLIMATOLOGY OF SOUTHERLY CHANGES AT CHRISTCHURCH, NEW ZEALAND, 1980-1984. R. N. Ridley, New Zealand Meteorological Service, Christchurch, New Zealand

PI.10 THE USE OF SATELLITE MEASUREMENTS TO EVALUATE BIASES BETWEEN RADIOSONDE TYPES. Larry M. McMillin, M. E. Gelman, A. Sanyal and M. Sylva, National Environmental Satellite, Data and Information Service (NESDIS), Washington, D. C.

PI.11 THE TYPICAL SHAPE FUNCTION SIMULTANEOUS RETRIEVAL SCHEME. Michael J. Uddstrom, New Zealand Meteorological Service, Wellington, New Zealand

PI.12 THE MIDLATITUDE RESPONSE OF THE SOUTHERN HEMISPHERE CIR CULATION TO FOR CING BY ANT ARCTICA. Ian N. James, Univ. of Reading, Reading, England

PI.13 FORECASTING VISIBILITY IN THE VICINITY OF MCMURDO, ANTARCTICA. Robert J. Renard and Robert A. Hale, Naval Postgraduate School, Monterey, Calif.

P1.14 THE POLEW ARD EXTENT OF THE SOUTHERN HEMISPHERE HADLEY CIR CULATION. Timothy T. Gibson, Univ. of Melbourne, Parkville, Vic., Australia

P1.15 MONTHLY-A VER AGED GLOBAL DISTRIBUTION OF HEATING FOR THE PLANETARY CIR CULATION DURING THE GWE. Donald R. Johnson and Todd K. Schaack, Univ. of Wisconsin, Madison, Wis.

P1.16 SOUTHERN HEMISPHERE CIRCULATION STATISTICS FOR WATER VAPOUR FROM GFDL AND AUSTRALIAN ANALYSES. David Karoly, Monash Univ., Clayton, Vic., Australia; and Abraham H. Oort, Princeton Univ., Princeton, N.J.

PI.17 BAROCLINIC ADJUSTMENT IN THE SOUTHERN HEMISPHERE DUR ING THE FGGE. N. Mole and Ian N. James, Univ. of Reading, Reading, England 
SESSION PI: POSTER SESSION (continued)

PI.18 SOME CHARACTERISTICS OF 500 MB BLOCKING AND ZONAL FLOWS IN THE SOUTHERN HEMISPHERE. Lesley F. Tarleton, Univ. of Colorado, Boulder, Colo.

PI.19 SENSITIVITY STUDIES ON NUCLEAR WINTER EFFECTS IN THE SOUTHERN HEMISPHERE. A. Barrie Pittock, CSIRO, Mordialloc, Vic., Australia

PI.20 A COMPARISON BETWEEN THE BOLIVIAN AND TIBETAN UPPER ANTICYCLONES. G. V. Rao, Saint Louis Univ., Saint Louis, Mo; and Henry van de Boogaard, NCAR, Boulder, Colo.

PI.21 NORTH AUSTRALIAN CLOUD LINES: DEFINITION AND EVOLUTION: Wasyl Drosdowsky and Greg J. Holland, BMRC, Melbourne, Vic., Australia

P1.22 ON THE MECHANISMS OF BORE FORMATION IN NORTHERN AUSTRALIA. Sabine P. Haase, Monash Univ., Clayton, Vic., Australia

P1.23 THREE DIMENSIONAL NUMERICAL SIMULATIONS OF SEA BREEZES OVER CAPE YORK PENINSULA. Julie A. Noonan, Monash Univ., Clayton, Vic., Australia

P1.24 THE AUSTRALIAN TROPICS: A SPAWNING GROUND FOR UNDULAR BORES IN THE LOWER ATMOSPHERE. Roger K. Smith, Monash Univ., Clayton, Vic., Australia

P1.25 VERIFICATION OF THE ELIASSEN-PALM RELATIONSHIP OVER SOUTHERN AFRICA. Michael S. J. Harrison, Univ. of Witwatersrand, Johannesburg, South Africa

PI.26 ANOMALIES IN SUMMER MONSOON RAINFALL OVER INDIA AND RELATIONSHIPS WITH THE SOUTHERN HEMISPHERIC SEA LEVEL PRESSURE. U. C. Mohanty, Indian Inst. of Technology, New Delhi, India; and Harry van Loon, NCAR, Boulder, Colo.

PI.27 CONTRIBUTION TO CENTRAL CHILE DYNAMIC CLIMATOLOGY. N. Saavedra, Univ. of Concepcion, Concepcion, Chile

6:30 PM

THURS DEC 4 $8: 30 \mathrm{AM}$

$9: 15 \mathrm{AM}$

ICEBREAKER

SESSION 7: GENERAL CIRCULATION MODELING (continued)

Chairperson: Peter Webster, Pennsylvania State Univ., University Park, Pa.

7.5 THE ROLE OF DIABATIC HEATING FOR THE MAINTENANCE OF QUASI-STATIONARY WAVES IN THE SOUTHERN HEMISPHERE. Erich Roeckner, Univ. of Hamburg, Hamburg, Federal Republic of Germany

7.6 GCM STUDY ON THE MAINTENANCE OF THE JUNE 1982 BLOCKING IN THE SOUTHERN HEMISPHERE. Eugenia Kalnay, NASA/GSFC, Greenbelt, Md.; King tse Mo, Univ. of Maryland, College Park, Md.; and J. Pfaendtner, Sigma Data Services, Greenbelt, Md.

A POSSIBLE CONTRIBUTION TO THE BLOCKINGS OVER THE SOUTH ATLANTIC. Ernesto H. Berbery and Mario N. Nunez, Univ. of Buenos Aires, Buenos Aires, Argentina

\section{SESSION 8: THE STRATOSPHERE IN THE SOUTHERN HEMISPHERE}

Chairperson: Peter Webster, Pennsylvania State Univ., University Park, Pa. CLIMATOLOGY AND INTERANNUAL VARIABILITY OF WAVE, MEAN-FLOW INTERACTION DURING WINTER AND SPRING IN THE SOUTHERN HEMISPHERE. Carlos R. Mechoso and John D. Farrara, Univ. of California, Los Angeles, Calif. THE SOUTHERN WINTER TROPOSPHERE AND STRATOSPHERE. William J. Randel, NCAR, Boulder, Colo. 
THURS DEC 4

$10: 20 \mathrm{AM}$

10:45 PM

$11: 15$ AM

12:15 PM

$1: 30$ PM
SESSION 8: THE STRATOSPHERE IN THE SOUTHERN HEMISPHERE (continued)

8.3

LOW-FREQUENCY OSCILLATIONS OF THE LARGE-SCALE STRATOSPHERIC TEMPERATURE FIELD. Xin-Hai Gao and John L. Stanford, lowa State Univ., Ames, Iowa

8.4 ISENTROPIC ANALYSIS OF SOUTHERN HEMISPHERE MEDIUM SCALE EDDIES BASED ON NIMBUS--7 LIMS TEMPERATURE AND TRACE CONSTITUENT DATA. T. Miles and W. L. Grose, NASA/Langley Research Center, Hampton, Va.

TEA - COFFEE BREAK

SESSION 8: THE STRATOSPHERE IN THE SOUTHERN HEMISPHERE (continued)

Chairperson: Vernon E. Kousky, NMC, Washington, D.C.

8.5 OBSERVATIONS OF THE STRATOSPHERIC FINAL WARMINGS IN THE TWO HEMISPHERES. Koji Yamazaki, Meteorological Research Inst., Tsukuba, Ibaraki, Japan

8.6

A FORMULATION OF THE STRATOSPHERE-TROPOSPHERE EXCHANGE PROCESSES AND AN OBJECTIVE DETERMINATION OF THE TROPOPAUSE LEVEL. Ming-Ying Wei, Univ. of Wisconsin, Madison, Wis.

RESERVE PAPER FOR SESSION 8:

8.7 THE LIFE CYCLES OF VERTICALLY PROPAGATING PLANETARY WAVES IN THE SOUTHERN HEMISPHERE WINTER. William J. Randel, NCAR, Boulder, Colo; and Duane E. Stevens, Colorado State Univ., Ft. Collins, Colo.

SESSION 9: TROPICAL METEOROLOGY IN THE SOUTHERN HEMISPHERE

Chairperson: Vernon E. Kousky, NMC, Washington, D.C.

9.1 SEASONAL VARIATION OF THE 40-50 DAY OSCILLATION IN THE TROPICS. Roland A. Madden, NCAR, Boulder, Colo. (Invited Paper)

9.2 30-60 DAY ATMOSPHERIC TELECONNECTION PATTERNS DURING THE SOUTHERN HEMISPHERE SUMMER. Takio Murakami, Univ. of Hawaii at Manoa, Honolulu, Hawaii

9.3 EQUATOR-CROSSING MASS FLOW AND ITS EFFECTS ON THE HURRICANES OCCURRENCE OVER SOUTHERN HEMISPHERE. Qian Ping and Wang-Jiagyi, National Marine Environmental Forecasting Center, Beijing, The People's Republic of China

RESERVE PAPER FOR SESSION 9:

9.4 SIGNIFICANCE OF THE SOUTH PACIFIC CONVERGENCE ZONE (SPCZ) IN THE ENERGY BUDGET OF THE SOUTHERN HEMISPHERE TROPICS. James W. Hurrell and Dayton G. Vincent, Purdue Univ., W. Lafayette, Ind.

LUNCH BREAK

SESSION 10: AUSTRALIAN TROPICS

Chairperson: Kamal Puri, BMRC, Melbourne, Vic., Australia

10.1 THE EQUATORIAL MESOSCALE EXPERIMENT: (EMEX) A TOGA PROCESS STUDY IN THE AUSTRALIAN NORTHWEST MONSOON. Peter J. Webster, Pennsylvania State Univ., University Park, Pa.; and Robert A. Houze, Jr., Univ. of Washington, Seattle, Wash. (Invited Paper)

10.2 THE BMRC AUSTRALIAN MONSOON EXPERIMENT. Greg J. Holland and John L. McBride, BMRC, Melbourne, Vic., Australia

10.3 ON THE STRUCTURE AND DYNAMICS OF THE TROPOSPHERE OVER THE INDONESIAN--AUSTRALIA REGION. Harry H. Hendon, CSIRO, Mordialloc, Vic., Australia 
THURS DEC 4

3:30 PM

4:00 PM

5:30 PM

6:30 PM

FRI DEC 5

$8: 30$ AM
SESSION 10: AUSTRALIAN TROPICS (continued)

10.4 TROPICAL CYCLONES IN THE SOUTHERN HEMISPHERE SUMMER MONSOON. John L. McBride, BMRC, Melbourne, Vic., Australia (Invited Paper)

10.5 ENVIRONMENTAL EFFECTS ON TROPICAL CYCLONIC MOTION. Jennie Evans-Lopez, Greg J. Holland and Noel E. Davidson, BMRC, Melbourne, Vic., Australia

10.6 TROPICAL/SUBTROPICAL INTERACTIONS DUR ING BLOCKING EVENTS. Geof Love and Philip Riley, Bureau of Meteorology, Darwin, N. T., Australia

RESER VE PAPER FOR SESSION 10:

10.7 ABRUPT SHIFTING OF THE JET STREAM OVER THE AUSTRALIAN REGION DURING MONSOON ONSET. Tsing-Chang Chen and Ming-Cheng Yen, Iowa State Univ., Ames, lowa

TEA - COFFEE BREAK

\section{SESSION 11: CIRCULATION NEAR AFRICA}

Chairperson: John L. McBride, BMRC, Melbourne, Vic., Australia

11.1 CLASSIFICATION OF SYNOPTIC WEATHER REGIMES IN SOUTH AFRICA BY DISCR IMINANT ANAL YSIS. Roseanne Diab, Univ. of Natal, Durban, South Africa; and Michael Garstang, Univ. of Virginia, Charlottesville, Va.

11.2 THE DIURNAL VARIATION IN SUMMER RAINFALL IN SOUTH AFRICA. Stephen Harangozo, Water Research Commission, Pretoria, South Africa

11.3 CIR CULATION VARIATIONS ON A SEMI--ANNUAL CYCLE OVER SOUTHERN AFRICA. Michael S. J. Harrison, Univ. of Witwatersrand, Johannesburg, South Africa

11.4 THE THREE-DIMENSIONAL PRESSURE FIELD OVER AFRICA. J. K. Patnaik, J. K. Ng'ang'a and P. M.R. Kiangi, Univ. of Nairobi, Nairobi, Kenya

11.5 ON THE EVALUATION OF THE CONVECTIVE POTENTIAL OF THE AIR MASSES OVER SOUTHERN AFRICA AND THE NEIGHBOURING OCEANS. Nicolas Besleaga, National Meteorological Dept., Paris, France

11.6 SEASONAL AND INTER ANNUAL HEAT FLUXES OVER THE AGULHAS RETROFLECTION REGION. N. D. Walker and R. Mey, National Research Inst. for Oceanography, Stellenbosch, South Africa

\section{ADJOURN}

BANQUET

\section{SESSION 12: SOUTHERN OSCILLATION IN THE SOUTHERN HEMISPHERE}

Chairperson: Neville Nicholls, BMRC, Melbourne, Vic., Australia

12.1 THE SOUTHERN OSCILLATION ON THE SOUTHERN HEMISPHERE. Harry van Loon, NCAR, Boulder, Colo. (Invited Paper)

12.2 LINEAR MODELS OF EQUATOR IAL SST'S. Nick E. Graham, Univ. of California, Santa Barbara Calif., Tim P. Barnett and J. Michaelsen, Scripps Institution of Oceanography, La Jolla, Calif.

12.3 SOUTHERN HEMISPHERE CIR CULATION FEATURES ASSOCIATED WITH EL NINO--SOUTHER N OSCILLATION EVENTS. David J. Karoly, Monash Univ., Clayton, Vic., Australia

12.4 OCEAN-ATMOSPHERE INTER ACTIONS DUR ING THE 1950-1979 PERIOD. Abraham H. Oort and Yi-Hong Pan, Princeton Univ., Princeton, N.J. 


\section{FRI DEC 5}

$10: 20 \mathrm{AM}$

$10: 45 \mathrm{AM}$

12:15 PM

$1: 30$ PM
SESSION 12: SOUTHERN OSCILLATION IN THE SOUTHERN HEMISPHERE (continued)

12.5 A NEW THEOR Y OF FAST AND SLOW TELECONNECTIONS. Peter $\mathrm{J}$. Webster and H. R. Chang, Pennsylvania State Univ., University Park, Pa.

12.6 METEOROLOGICAL ANOMALIES OVER THE SOUTH PACIFIC DURING W ARM AND COLD PHASES OF THE SOUTHERN OSCILLATION. George N. Kiladis, Univ, of Colorado, Boulder, Colo.; and Harry van Loon, NCAR, Boulder, Colo.

RESER VE PAPER FOR SESSION 12:

12.7 MODELING THE SOUTHERN OSCILLATION AND ASSOCIATED GLOBAL SCALE VARIAT IONS IN SEA LEVEL PRESSURE. Tim P. Barnett and J. O. Roads, Scripps Institution of Oceanography, La Jolla, Ca.

TEA - COFFEE BREAK

SESSION 13: THE SOUTHERN OSCILLATION AND TELECONNECTIONS IN THE SH

Chairperson: Harry van Loon, NCAR, Boulder, Colo.

13.1 PREDICTING SOUTHERN HEMISPHERE CLIMATE ANOMALIES AND IMPACTS WITH THE SOUTHERN OSCILLATION. Neville Nicholls, BMRC, Melbourne, Vic., Australia (Invited Paper)

13.2 PREDICTABILITY OF DROUGHTS IN THE SOUTHERN HEMISPHERE. Peter B. Wright, Max Planck Institute for Meteorology, Hamburg, Federal Republic of Germany

13.3 RELATIONS BETWEEN THE SOUTHERN OSCILLATION AND UPPER WINDS OVER THE AUSTR ALIAN REGION. Mark Williams, Bureau of Meteorology, Melbourne, Vic., Australia

13.4 ANTARCTIC SEA ICE-ATMOSPHERE SIGNAL OF THE SOUT HERN OSCILLATION. Andrew M. Carleton, Indiana Univ., Bloomington, Ind.

1 3.5 SOME ASPECTS OF INTER ANNUAL VARIATIONS OF ANTARCTICA TEMPER ATURES AND ITS TELECONNECTIONS. R. K. Verma, Indian Inst. of Tropical Meteorology, Pune, India

\section{LUNCH BREAK}

\section{SESSION 14: SOUTH AMERICAN METEOROLOGY}

Chairperson: Mario M. Nunez, Univ. of Buenos Aires, Buenos Aires, Argentina

14.1 DROUGHT IN SOUTHERN BRAZIL AND RELATED ATMOSPHERIC ANOMALIES. Vernon E. Kousky and Darci P. Casarin, NMC, Washington, D.C.

14.2 INTER ANNU AL CLIMATIC VARIABILITY IN SOUTH AMERICA AND THE SOUTHERN OSCILLATION. Patricio Aceituno, Univ. of Wisconsin, Madison, Wịs.

14.3 PRECIPITATION AND CIRCULATION ANOMALIES IN SOUTH AMERICA AND THE 1982-83 EL NINO/SOUTHERN OSCILLATION EPISODE. Carlos A. Nobre and N. O. Renno, INPE, Sao Jose dos Campos, Brazil

14.4 THE ANOMALOUS RAINFALL IN NOR THEAST OF BRAZIL IN 1985. Iracema F. A. Cavalcanti, Dept. of Meteorology, Sao Jose dos Campos, Brazil

14.5 TRACE GAS EXCHANGES AND TRANSPOR TS OVER THE AM AZONIAN RAINFOREST. Michael Garstang, Univ. of Virginia, Charlottesville; Robert Harriss and Edward Browell, NASA/Langley Research Center, Hampton, Va.; Joanne Simpson, NASA/GSFC, Greenbelt, Md.; Stephen Wofsy, Harvard Univ., Cambridge, Mass; M. O. Andreae, Florida State Univ., Tallahassee, Fla. and R. A. Rasmussen, Oregon Graduate Center, Beaverton, Ore. 
FRI DEC 5

3:00 PM

3:30 PM
SESSION 14: SOUTH AMERICAN METEOROLOGY (continued)

14.6 MESOSCALE CONVECTIVE COMPLEXES OVER SOUTH AMERICA. Ines Velasco, Univ. of Buenos Aires, Buenos Aires, Argentina; and J. Michael Fritsch, Pennsylvania State Univ., University Park, Pa.

COFFEE BREAK

\section{SESSION 15: AFRICA AND THE SOUTHERN OSCILLATION}

Chairperson: To be announced

15.1 THE SOUTHERN OSCILLATION AND FLOW FIELDS OVER SOUTHERN AFRICA. J. A. Lindesay and Michael S. J. Harrison, Univ. of Witwatersrand, Johannesburg, South Africa

15.2 VARIATIONS IN ATMOSPHERIC CIRCULATION OVER SOUTHERN AFRICA DURING THE DRY SPELL OF THE SIXTIES AND WET SPELL OF THE SEVENTIES. Peter D. Tyson, Univ. of Witwatersrand, Johannesburg, South Africa

15.3 SOUTH AFRICAN RAINFALL RELATED TO W ARM AND COLD EVENTS. Gerrit C. Schulze, The Weather Bureau, Pretoria, South Africa

15.4 RELATIONSHIP BETWEEN SEASONAL RAINFALL IN EAST AFRICA AND THE SOUTHERN OSCILLATION. Laban J. Ogallo, Univ. of Nairobi, Nairobi, Kenya

15.5 RAINFALL VARIABILITY IN SOUTHERN AND EQUATORIAL AFRICA: ITS RELATION TO ATLANTIC SEA-SURFACE TEMPERATURES AND THE SOUTHERN OSCILLATION. Sharon E. Nicholson, Florida State Univ., Tallahassee, Fla.

CLOSING 


\section{LIMITED SALE}

\section{CONFERENCE \\ PREPRINTS/PROCEEDINGS}

AVAILABLE FROM

THE

\section{AMERICAN METEOROLOGICAL SOCIETY}

\section{4}

Non

Member

15th Technical Conference on Hurricane and Tropical Meteorology ... 20.00

30.00

Third Conference on Meteorology of the Coastal..................... 15.00

20.00

Ninth Conference on Weather Modification

15.00

20.00

Seventh International Conference on Atmospheric Electricity ........... 20.00

30.00

10th Conference on Weather Forecasting Analysis

20.00

30.00

Conference on Satellite Meteorology/Remote Sensing and

Applications.................................................. 20.00

30.00

22nd Conference on Radar Meteorology

22.00

32.00

Fourth Joint Conference on Applications of Air Pollution Meteorology

20.00

30.00

Third Conference on Mountain Meteorology. 15.00

20.00

\section{5}

Third Conference on Climate Variations: Symposium on Contemporary

Climate: $1850-2100$

International Conference on Interactive Information \& Procedures for

Meteorology, Oceanography, Hydrology. ...

30.00

16th Conference on Hurricanes and Tropical Meteorology

17th Conference on Agriculture and Forest Meteorology and Seventh

Conference on Biometeorology and Aerobiology (extended abstracts)

Seventh Conference on Numerical Weather Prediction

20.00

30.00

Second International Conference on the Aviation Weather System....

Conference on Aerospace and Range Meteorology

20.00

30.00

20.00

Ninth Conference on Probability and Statistics

\subsection{0}

20.00

14th Conference on Severe Local Storms

20.00

Sixth Conference on Hydrometeorology.

20.00

30.00

30.00

Seventh Symposium on Turbulence and Diffusion

20.00

30.00

30.00

\section{NOTE}

All publications must be prepaid before orders can be processed. Foreign payments must be made by a draft on a U.S. bank or by international money order payable in U.S. dollars. On all orders add $\$ 2.00$ postage and handling per publication. Orders received before 1 September 1986 may deduct $20 \%$ of the total cost.

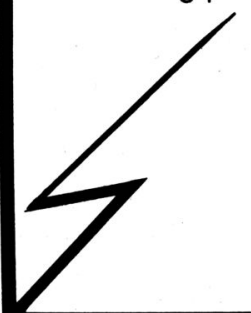

Send order and remittance to:

Publications Department

AMERICAN METEOROLOGICAL SOCIETY

45 Beacon Street

Boston, MA 02108-3639

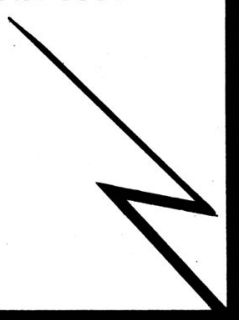

